\title{
Effect of Agricultural Practices on Hydrology and Water Chemistry in a Small Irrigated Catchment, Yakima River Basin, Washington
}

National Water-Quality Assessment Program

Scientific Investigations Report 2009-5030

U.S. Department of the Interior

U.S. Geological Survey 
This page left intentionally blank 


\section{Effect of Agricultural Practices on Hydrology and Water Chemistry in a Small Irrigated Catchment, Yakima River Basin, Washington}

By Kathleen A. McCarthy and Henry M. Johnson

National Water-Quality Assessment Program

Scientific Investigations Report 2009-5030 


\title{
U.S. Department of the Interior \\ KEN SALAZAR, Secretary
}

\author{
U.S. Geological Survey \\ Suzette M. Kimball, Acting Director
}

U.S. Geological Survey, Reston, Virginia: 2009

For more information on the USGS - the Federal source for science about the Earth, its natural and living resources, natural hazards, and the environment, visit http://www.usgs.gov or call 1-888-ASK-USGS

For an overview of USGS information products, including maps, imagery, and publications,

visit http://www.usgs.gov/pubprod

To order this and other USGS information products, visit http://store.usgs.gov

Any use of trade, product, or firm names is for descriptive purposes only and does not imply endorsement by the U.S. Government.

Although this report is in the public domain, permission must be secured from the individual copyright owners to reproduce any copyrighted materials contained within this report.

Suggested citation:

McCarthy, K.A., and Johnson, H.M., 2009, Effect of agricultural practices on hydrology and water chemistry in a small irrigated catchment, Yakima River basin, Washington: U.S. Geological Survey Scientific Investigations Report 2009-5030, 22 p. 


\section{Foreword}

The U.S. Geological Survey (USGS) is committed to providing the Nation with credible scientific information that helps to enhance and protect the overall quality of life and that facilitates effective management of water, biological, energy, and mineral resources (http://www.usgs.gov/). Information on the Nation's water resources is critical to ensuring long-term availability of water that is safe for drinking and recreation and is suitable for industry, irrigation, and fish and wildlife. Population growth and increasing demands for water make the availability of that water, now measured in terms of quantity and quality, even more essential to the long-term sustainability of our communities and ecosystems.

The USGS implemented the National Water-Quality Assessment (NAWOA) Program in 1991 to support national, regional, State, and local information needs and decisions related to water-quality management and policy (http://water.usgs.gov/nawqa). The NAWOA Program is designed to answer: What is the condition of our Nation's streams and ground water? How are conditions changing over time? How do natural features and human activities affect the quality of streams and ground water, and where are those effects most pronounced? By combining information on water chemistry, physical characteristics, stream habitat, and aquatic life, the NAWQA Program aims to provide science-based insights for current and emerging water issues and priorities. From 1991-2001, the NAWOA Program completed interdisciplinary assessments and established a baseline understanding of water-quality conditions in 51 of the Nation's river basins and aquifers, referred to as Study Units (http://water.usgs.gov/nawqa/studyu.html).

Multiple national and regional assessments are ongoing in the second decade (2001-2012) of the NAWQA Program as 42 of the 51 Study Units are reassessed. These assessments extend the findings in the Study Units by determining status and trends at sites that have been consistently monitored for more than a decade, and filling critical gaps in characterizing the quality of surface water and ground water. For example, increased emphasis has been placed on assessing the quality of source water and finished water associated with many of the Nation's largest community water systems. During the second decade, NAWOA is addressing five national priority topics that build an understanding of how natural features and human activities affect water quality, and establish links between sources of contaminants, the transport of those contaminants through the hydrologic system, and the potential effects of contaminants on humans and aquatic ecosystems. Included are topics on the fate of agricultural chemicals, effects of urbanization on stream ecosystems, bioaccumulation of mercury in stream ecosystems, effects of nutrient enrichment on aquatic ecosystems, and transport of contaminants to public-supply wells. These topical studies are conducted in those Study Units most affected by these issues; they comprise a set of multi-Study-Unit designs for systematic national assessment. In addition, national syntheses of information on pesticides, volatile organic compounds (VOCs), nutrients, selected trace elements, and aquatic ecology are continuing.

The USGS aims to disseminate credible, timely, and relevant science information to address practical and effective water-resource management and strategies that protect and restore water quality. We hope this NAWQA publication will provide you with insights and information to meet your needs, and will foster increased citizen awareness and involvement in the protection and restoration of our Nation's waters.

The USGS recognizes that a national assessment by a single program cannot address all water-resource issues of interest. External coordination at all levels is critical for cost-effective management, regulation, and conservation of our Nation's water resources. The NAWQA Program, therefore, depends on advice and information from other agencies — Federal, State, regional, interstate, Tribal, and local—as well as nongovernmental organizations, industry, academia, and other stakeholder groups. Your assistance and suggestions are greatly appreciated.

Matthew C. Larsen

Associate Director for Water 
This page left intentionally blank 


\section{Contents}

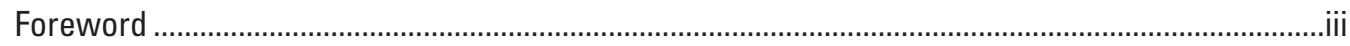

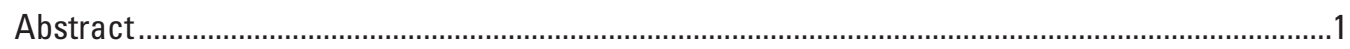

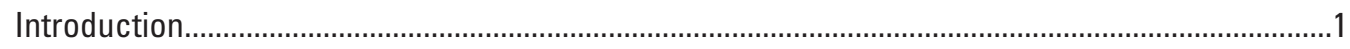

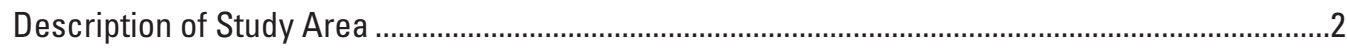

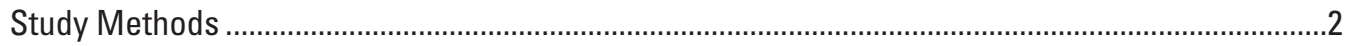

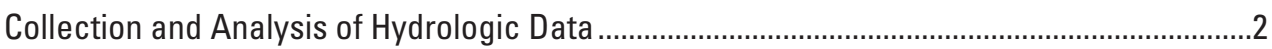

Collection and Analysis of Water-Chemistry Data ..................................................................

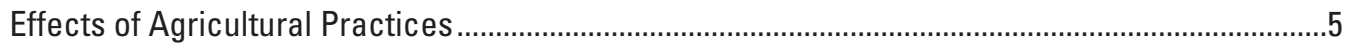

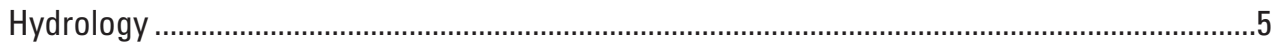

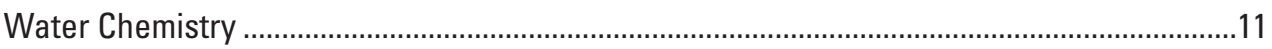

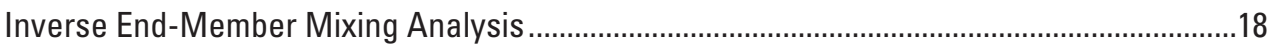

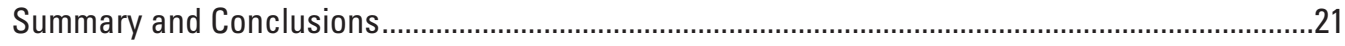

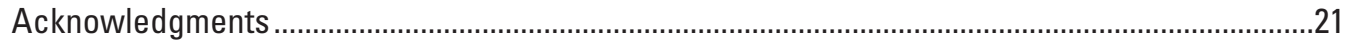

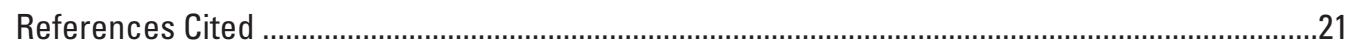

\section{Figures}

Figure 1. Map showing location of the DR2 catchment and data-collection sites,

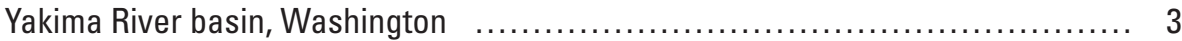

Figure 2. Graph showing data-collection dates in the DR2 catchment, Yakima River basin, Washington .......................................................

Figure 3. Graph showing estimated 2003 water balance for the DR2 catchment, Yakima

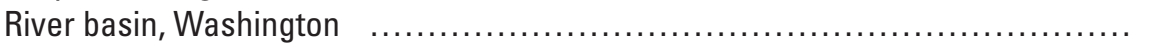

Figure 4. Hydrograph showing discharge for the DR2 Catchment surface-water

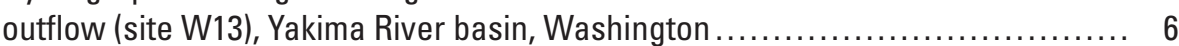

Figure 5. Diagram showing conceptualization of the hydrology of the DR2 catchment,

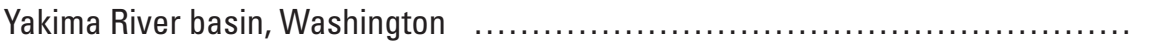

Figure 6. Graphs showing wWater levels in well pairs in the DR2 catchment, Yakima

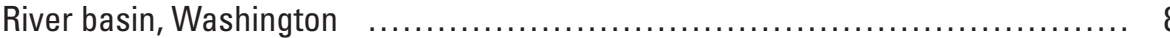

Figure 7. Graphs showing water levels and water temperatures in ground water in the

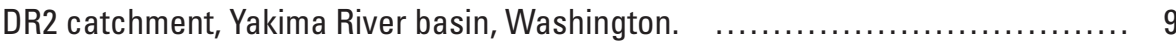

Figure 8. Graph showing ground-water head gradient (black line) and temperature (grey line) at site W23, DR2 catchment, Yakima River basin, Washington .......... 9

Figure 9. Graph showing estimated ground-water recharge dates in the DR2

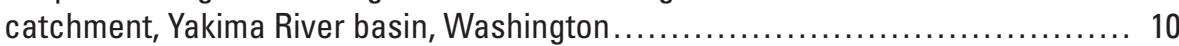

Figure 10. Graph showing abundance of deuterium and oxygen-18 in water samples from the DR2 catchment, Yakima River basin, Washington $\ldots \ldots \ldots \ldots \ldots \ldots \ldots \ldots \ldots \ldots \ldots$

Figure 11. Graph showing abundances of oxygen-18 and nitrogen-15 in nitrate in water samples from the DR2 catchment, Yakima River basin, Washington .............. 12

Figure 12. Boxplot showing distribution of specific conductance of water samples from

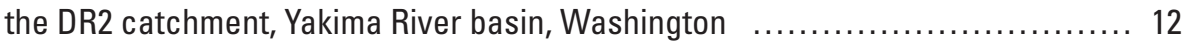

Figure 13. Boxplots showing distribution of concentrations of major solutes in water samples from the DR2 catchment, Yakima River basin, Washington 


\section{Figures-Continued}

Figure 15. Graph showing vertical temperature profile measured in the streambed in the DR2 catchment, Yakima River basin, Washington, September 2004 .

Figure 14. Boxplots showing distribution of concentrations of nitrate and soluble reactive phosphorus in water samples from the DR2 catchment, Yakima River basin, Washington

Figure 16. Graphs showing concentrations of selected solutes (square symbols) and stream discharge (solid line) at the DR2 catchment outflow (site W13),

Yakima River basin, Washington

Figure 17. Boxplots showing distribution of concentrations of selected solutes measured in the DR2 catchment outflow components, and concentrations calculated for hypothetical seasonal agricultural flow (SAF), Yakima River basin, Washington

\section{Tables}

Table 1. Excess nitrogen gas (N2) measured in the DR2 catchment, Yakima River basin, Washington

Table 2. Composition of surface flow-system components during the irrigation season in the DR2 catchment, Yakima River basin, Washington

\section{Conversion Factors and Datums}

\section{Conversion Factors}

\begin{tabular}{lcl}
\hline \multicolumn{1}{c}{ Multiply } & By & \multicolumn{1}{c}{ To obtain } \\
\hline centimeter $(\mathrm{cm})$ & 0.3937 & inch (in.) \\
kilometer $(\mathrm{km})$ & 0.6214 & mile (mi) \\
liter (L) & 33.82 & ounce, fluid (fl. oz) \\
liter (L) & 0.2642 & gallon (gal) \\
meter $(\mathrm{m})$ & 3.281 & foot (ft) \\
cubic meters per second $\left(\mathrm{m}^{3} / \mathrm{s}\right)$ & 35.31 & cubic feet per second $\left(\mathrm{ft}^{3} / \mathrm{s}\right)$ \\
millimeter $(\mathrm{mm})$ & 0.03937 & inch (in.) \\
square kilometer $\left(\mathrm{km}^{2}\right)$ & 247.1 & acre \\
square kilometer $\left(\mathrm{km}^{2}\right)$ & 0.3861 & square mile $\left(\mathrm{mi}^{2}\right)$ \\
\hline
\end{tabular}

Temperature in degrees Celsius $\left({ }^{\circ} \mathrm{C}\right)$ may be converted to degrees Fahrenheit $\left({ }^{\circ} \mathrm{F}\right)$ as follows:

$$
{ }^{\circ} \mathrm{F}=\left(1.8 x^{\circ} \mathrm{C}\right)+32 .
$$

Specific conductance is given in microsiemens per centimeter at 25 degrees Celsius $\left(\mu \mathrm{S} / \mathrm{cm}\right.$ at $\left.25^{\circ} \mathrm{C}\right)$. Concentrations of chemical constituents in water are given either in milligrams per liter ( $\mathrm{mg} / \mathrm{L})$ or micrograms per liter $(\mu \mathrm{g} / \mathrm{L})$.

Datums

Vertical coordinate information is referenced the North American Vertical Datum of 1988 (NAVD 88). Horizontal coordinate information is referenced to the North American Datum of 1927 (NAD 27). 


\title{
Effect of Agricultural Practices on Hydrology and Water Chemistry in a Small Irrigated Catchment, Yakima River Basin, Washington
}

\author{
By Kathleen A. McCarthy and Henry M. Johnson
}

\begin{abstract}
The role of irrigation and artificial drainage in the hydrologic cycle and the transport of solutes in a small agricultural catchment in central Washington's Yakima Valley were explored using hydrologic, chemical, isotopic, agedating, and mineralogical data from several environmental compartments, including stream water, ground water, overland flow, and streambed pore water. A conceptual understanding of catchment hydrology and solute transport was developed and an inverse end-member mixing analysis was used to further explore the effects of agriculture in this small catchment. The median concentrations of major solutes and nitrates were similar for the single field site and for the catchment outflow site, indicating that the net effects of transport processes for these constituents were similar at both scales. However, concentrations of nutrients were different at the two sites, suggesting that field-scale variations in agricultural practices as well as nearstream and instream biochemical processes are important components of agricultural chemical transformation and transport in this catchment. This work indicates that irrigation coupled with artificial drainage networks may exacerbate the ecological effects of agricultural runoff by increasing direct connectivity between fields and streams and minimizing potentially mitigating effects (denitrification and dilution, for example) of longer subsurface pathways.
\end{abstract}

\section{Introduction}

Agriculture is widely recognized as a major source of nutrients and other potential contaminants to water bodies throughout the world. In an assessment of the effects of human activity on water quality, the U.S. Environmental Protection Agency $(2002,2005)$ listed agricultural practices and hydrological modifications as the two most important causes of water-quality impairment to streams assessed during the 2000 National Water-Quality Inventory. Because irrigation can extensively modify the hydrology of small catchments, these findings indicate that irrigated agriculture may be of particular importance as a source of water-quality impairment.

In the Western United States, between one-quarter and one-third of harvested cropland is irrigated (Schaible, 2004). Due to the nature of the crops and relatively high yields, however, this irrigated cropland accounts for approximately three-quarters of the value of crops sold in the West (Gollehon and Quinby, 2000). It is estimated that the global demand for food will more than double over the coming decades (Green and others, 2005), and it is likely that much of the increased demand will be met by irrigated agriculture.

In the Western United States, irrigation is typically applied to naturally arid or semiarid landscapes, where few natural surface drainage routes exist. To keep such areas agriculturally productive, artificial surface and shallow subsurface drainage networks often are constructed to facilitate runoff. In many of these networks, virtually all water carried by the drains is agricultural runoff, and little or no dilution from naturally occurring ground-water base flow or storm-generated surface runoff occurs. As a result, in addition to the diffuse nonpoint-source contamination typically associated with agriculture, drainage networks in irrigated areas can act as point sources of contaminants to receiving streams and lakes. 
In the work presented here, the hydrologic cycle and the transport of solutes in a small, irrigated catchment in the Yakima Valley of central Washington are described on the basis of the results of analyses of various hydrologic, chemical, isotopic, age dating, and mineralogical data from several environmental compartments, including stream water, ground water, overland flow, and streambed pore water. A conceptual model of catchment hydrology and solute transport is developed and an inverse end-member mixing analysis is used to further explore the effects of agriculture in this small irrigated catchment.

These data were collected as part of a larger effort by the U.S. Geological Survey (USGS) National Water-Quality Assessment (NAWQA) program. To gain insights into how environmental processes and agricultural practices interact to determine the transport and fate of agricultural chemicals in the environment, the USGS NAWQA program conducted in-depth investigations at five agricultural study areas across the country during 2003-04. The design of the overall study is described in detail by Capel and others (2008). Companion studies report on the transport and processing of agricultural chemicals in surface water (Domagalski and others, 2008; Duff and others, 2008); transport in the subsurface (Green and others, 2008; Steele and others, 2008), and ground-water/ surface-water interactions (Duff and others, 2008; Essaid and others, 2008; Puckett and others, 2008).

\section{Description of Study Area}

The DR2 catchment is a small $\left(5.5 \mathrm{~km}^{2}\right)$ subbasin in the Yakima Valley of central Washington (fig. 1). A detailed description of the catchment is available in Payne and others (2007). Three characteristics of the catchment particularly relevant to the transport and fate of agricultural chemicals are:

(1) irrigation practices, (2) crop heterogeneity, and (3) subsurface drainage. These characteristics are discussed here briefly.

Land use in the DR2 catchment is nearly 90 percent agriculture, and, with less than $18 \mathrm{~cm}$ of annual precipitation, 95 percent of the agriculture is irrigated. The demand for irrigation water is met by withdrawals from the Yakima River that are delivered to the catchment through the Sunnyside Canal (fig. 1) and dispersed throughout the catchment by secondary delivery canals. At the individual field scale, water is applied to crops by various methods, including rill, drip, and sprinkler systems. Although the use of rill irrigation is slowly diminishing in the catchment as growers convert to more efficient sprinkler and drip systems, it remains the predominant method due to economic, planting, harvesting, and other crop management considerations that make more efficient systems less practical.

A wide variety of crops are grown in the DR2 catchment (Payne and others, 2007). During the study period, crops and other agricultural activities included corn, grapes (for both wine and juice), asparagus, alfalfa, forage grass, pasture, and dairy/feedlot operations. Not only do crops - and therefore irrigation practices and chemical applications - vary considerably across this small catchment, they also vary from year to year in many fields.

Shallow subsurface flow in the area has been modified by an extensive system of buried drains. These drains exert a strong influence on the shallow ground-water system and its connection to surface water. However, most of the drainage system has been in place for many decades, and apart from the large, regional drains, the location and extent of the drains are not well known.

\section{Study Methods}

Hydrologic and water-quality data were collected from 38 sites in the study area: the irrigation delivery canal (W15), 18 wells (W20p-W32q), 17 streambed sites in 2 transects located near the mouth of DR2 (W51a-W64c), a field drain (W42), and the surface-water outflow of DR2 (W13) (fig. 1). Data collected included ground-water levels, stream stage, stream discharge, water-quality parameters, estimated groundwater recharge dates, stable isotope abundances in water and nitrate, and soil mineralogy.

\section{Collection and Analysis of Hydrologic Data}

Wells, piezometers, and drive points used for collection of ground-water and streambed data were installed as part of this study, following procedures described in Lapham and others (1997). Wells were constructed of 5-cm-diameter PVC with 1.5-m slotted PVC screens and were installed using either a hollow-stem auger or a mud rotary drill. The annulus around the screen was filled with silica sand, the remaining annulus was grouted with bentonite, and a cement cap was placed at land surface. Shallow wells were generally screened approximately $1 \mathrm{~m}$ or less below the water table; deeper wells were screened 7-12 $\mathrm{m}$ below the water table except at site W21, where wells also were screened at 16 and $26 \mathrm{~m}$ below the water table.

Piezometers and drive points at the streambed transects were installed in 10-cm-diameter hand-augered holes. Piezometers for measuring water levels had screened open intervals of $15 \mathrm{~cm}$, and drive points for water-sample collection had screened open intervals of $0.95 \mathrm{~cm}$. The annular space was filled with sand to a height of approximately $6-15 \mathrm{~cm}$ above the top of the screen and then with bentonite pellets to the level of the streambed. During well installation at most sites, samples of aquifer material were collected with a split-spoon sampler from the depth of the screened interval and submitted for mineralogical analysis by X-ray diffraction. After installation, wells were developed by pumping and surging and were allowed to equilibrate for at least 45 days before the first water samples were collected. Additional installation details are described by Capel and others (2008) and Puckett and others (2008). 


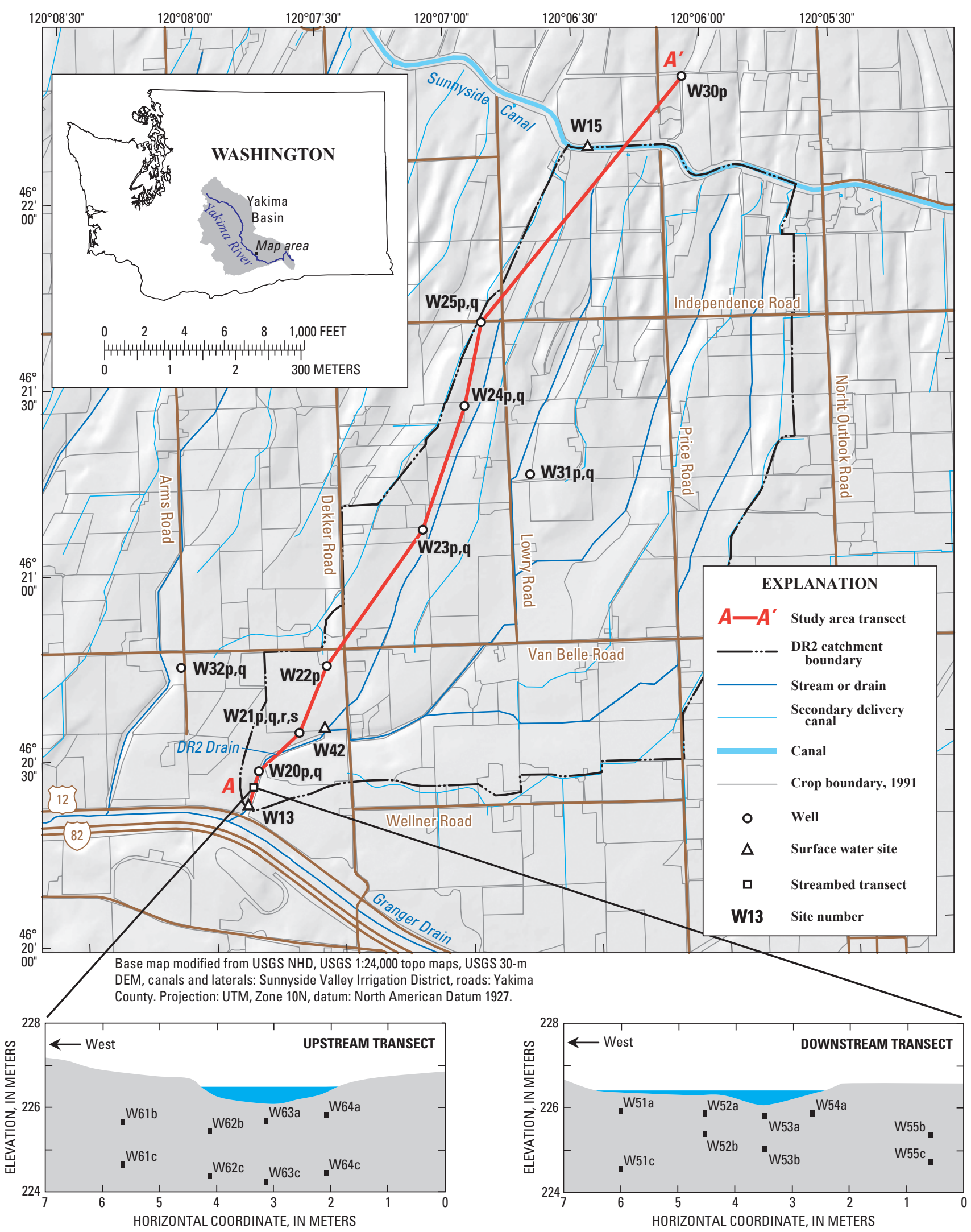

Figure 1. Location of the DR2 catchment and data-collection sites, Yakima River basin, Washington. 
Water-level data were collected manually from 16 wells, and water-level and temperature data were collected by electronic recorder from 6 shallow wells, the W23 well pair, and 1 streambed site. Recorder data were collected using Solinst Leveloggers (Model 3001 F15; range: 4 m; resolution: $0.1 \mathrm{~cm}$; accuracy: $4 \mathrm{~mm}$; Solinst Canada Ltd, Georgetown, Ontario, Canada) and Solinst Barologgers (Model M5), for atmospheric-pressure-change compensation. The temperature of water in the stream and at multiple depths below the streambed was recorded by suspending StowAway TidbiT Temperature Loggers (Onset Computer Corp. Pocasset, Massachusetts; range: -4 to $30^{\circ} \mathrm{C}$; accuracy: $\pm 0.2^{\circ} \mathrm{C}$ at $20^{\circ} \mathrm{C}$ ) within the piezometer clusters.

Discharge from the field drain was measured volumetrically, using a calibrated $19 \mathrm{~L}$ bucket and stopwatch. Stream discharge was measured near the catchment outlet using an AquaRod water-level sensor (Sequoia Scientific, Inc., Bellevue, Washington). The AquaRod was mounted in an existing, calibrated flume that is maintained by the Sunnyside Valley Irrigation District (Sunnyside, Washington). Irrigation and canal-leakage data were obtained from the Sunnyside Valley Irrigation District.

Precipitation data and daily crop-specific evapotranspiration data were obtained from the Harrah, Washington, station of the Pacific Northwest Cooperative Agricultural Weather Network (U.S. Department of the Interior, Bureau of Reclamation, Pacific Northwest Region; http://www.usbr. gov/pn/agrimet/, accessed January 6, 2009), located approximately $35 \mathrm{~km}$ from the study catchment. These evapotranspiration data were coupled with field-scale crop data obtained from land-use surveys (Payne and others, 2007) to estimate total catchment evapotranspiration. (Precipitation data from an onsite weather station were available, but the period of record was inadequate for use in the work reported here. The onsite data that were available agreed well with data from Harrah station, with differences in total precipitation less than 10 percent for the common periods of record.)

The quantities of ground water flowing into and out of the catchment were estimated from numerical simulations (Leon J. Kauffman, U.S. Geological Survey, written commun., 2006) using the MODFLOW code (Harbaugh and others, 2000). Ground-water flow paths were simulated (Leon J. Kauffman, U.S. Geological Survey, written commun., 2006) using the particle-tracking code MODPATH (Pollock, 1994).

\section{Collection and Analysis of Water-Chemistry Data}

During 2004, water samples were collected 6 times from the Sunnyside Canal (W15), 4 times from wells (W20pW32q) and streambed sites (W51a-W64c), 17 times from the field drain (W42), and 27 times from DR2 at the catchment outflow (W13) (fig. 2). Measurements of temperature, $\mathrm{pH}$, specific conductance, alkalinity, and dissolved oxygen were obtained onsite. Water samples were subsequently analyzed for nitrogen $(\mathrm{N})$ and phosphorus $(\mathrm{P})$ species, and for major solutes (calcium, magnesium, sodium, potassium, chloride, and silica). Selected samples also were analyzed for dissolved organic carbon (DOC), stable isotopes of water $\left({ }^{2} \mathrm{H}\right.$ and $\left.{ }^{18} \mathrm{O}\right)$, and stable isotopes of nitrate $\left({ }^{15} \mathrm{~N}\right.$ and $\left.{ }^{18} \mathrm{O}\right)$. Selected groundwater and streambed samples were analyzed for age-dating

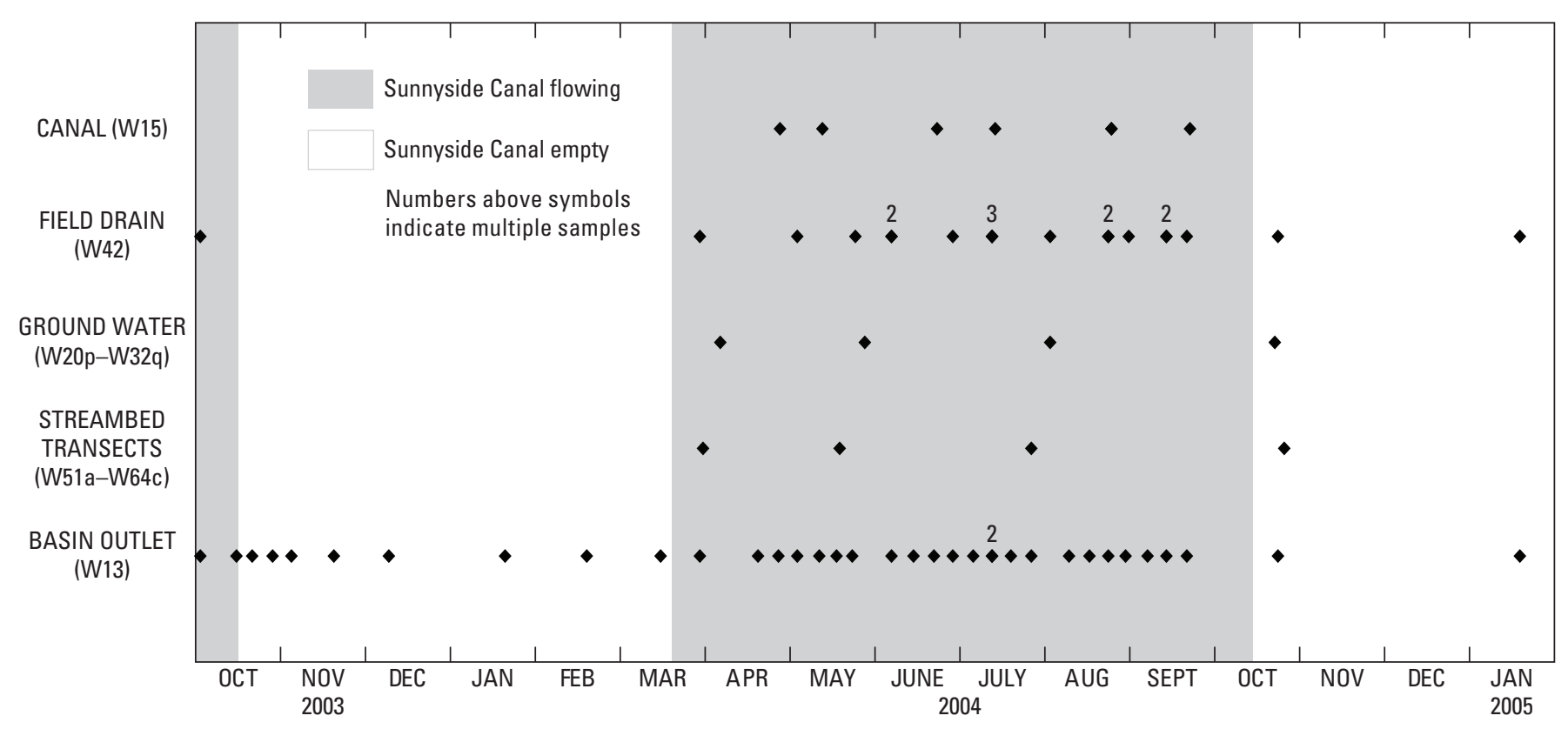

Figure 2. Data-collection dates in the DR2 catchment, Yakima River basin, Washington. 
constituents, including $\mathrm{CFCl}_{3}$ (CFC-11), $\mathrm{CF}_{2} \mathrm{Cl}_{2}$ (CFC-12), and $\mathrm{C}_{2} \mathrm{~F}_{3} \mathrm{Cl}_{3}(\mathrm{CFC}-113)$, sulfur hexafluoride $\left(\mathrm{SF}_{6}\right)$, and tritium $\left({ }^{3} \mathrm{H}\right)$, and for concentrations of dissolved $\mathrm{N}$ gas $\left(\mathrm{N}_{2}\right)$ and argon in order to estimate the amount of $\mathrm{N}$ present as a result of denitrification (Heaton and Vogel, 1981; Vogel and others, 1981; Böhlke and others, 2002; Green and others, 2008).

Further details of the instrumentation and the methods used for data collection, analysis, and quality control are described by Capel and others (2008, supplemental material). Additional information on sample-collection, analyses, and interpretation of dissolved-gas, stable-isotope, and groundwater-age data are available in Green and others (2008).

\section{Effects of Agricultural Practices}

\section{Hydrology}

Knowledge of how water moves through a catchment is fundamental to understanding the effects of agricultural practices. One of the primary objectives of this work, therefore, was to develop a conceptual model of the sources, distribution, and movement of water within the DR2 catchment. A simple water balance (fig. 3), estimated from 2003 data, provides insight into the overall hydrology of the catchment and the processes that influence agricultural effects on the environment in this study area.

Irrigation water, imported from the Yakima River, is the principal source of water to the catchment, accounting for nearly 60 percent of the total inflow. This irrigation water is delivered through the Sunnyside Canal (fig. 1)

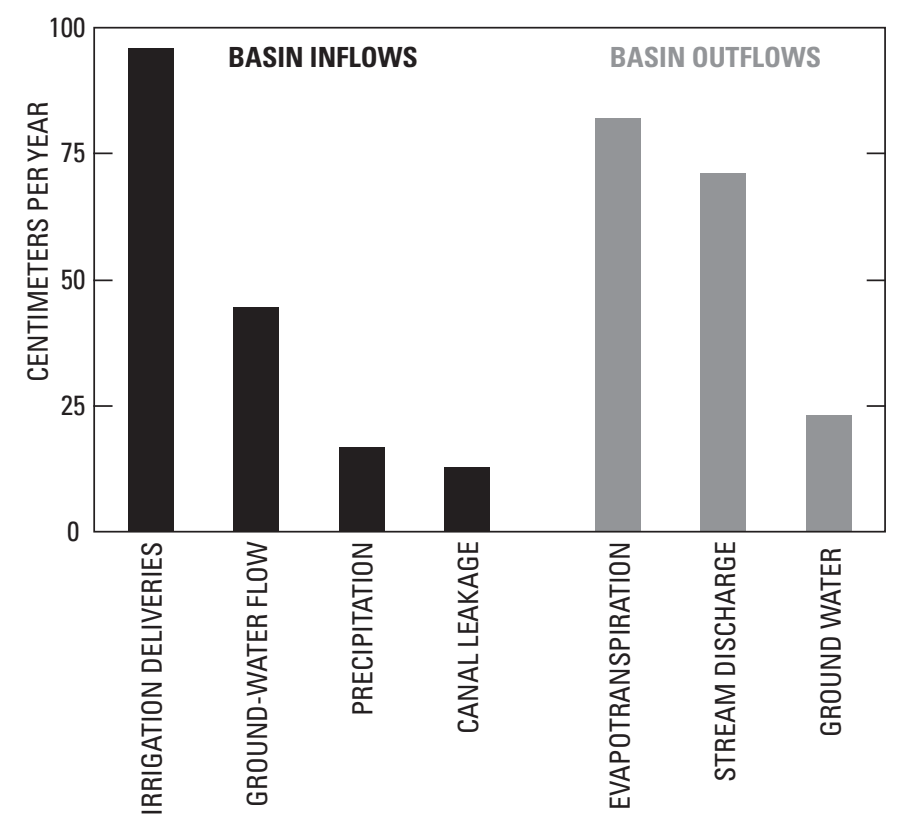

Figure 3. Estimated 2003 water balance for the DR2 catchment, Yakima River basin, Washington. and is transported throughout the catchment by a series of secondary canals, from which it is applied to crops and pasture. Rill irrigation - the predominant application method used in the catchment - typically results in 15 to 25 percent of the applied water running out the end of the furrows (U.S. Environmental Protection Agency, 2003; Eisenhauer and others, 2006; Schwankl and others, 2007). This tailwater is routed into surface or subsurface drains that eventually discharge to regional surface-water drains, such as DR2. Sprinkler irrigation - the other major water application method in DR2 - produces no tailwater in most circumstances. Most canal water diverted into the irrigation water delivery system is applied to the land surface; however, a small fraction of the diverted water goes unused as part of the normal operation of the gravity-driven irrigation-water delivery network. This end-of-system "operational spill" also is routed into the regional drainage network. Additional unused water may enter the drainage system due to a lag time between requests for changes in the delivery amount and the implementation of the request, the onset of unexpected cool or wet weather, system malfunctions (such as pipe breaks), and various on-farm exigencies.

Other primary sources of water to the catchment are ground water that flows into the area from north of the Sunnyside Canal, precipitation, and leakage from the Sunnyside Canal. Together, these four major sources contribute approximately $180 \mathrm{~cm}$ of water per year to the catchment. Evapotranspiration and stream discharge account for nearly 90 percent of the total catchment outflow. The third important component of outflow is ground water.

Irrigation is a key component of the hydrology of the DR2 catchment (fig. 3). In fact, there is no evidence that a surface-water system existed in the catchment before irrigated agriculture began in the area more than a century ago (Payne and others, 2007). In addition to creating an extensive surfacewater drainage network during the growing season, long-term irrigation has caused ground-water levels to rise, and the higher water table provides base flow that sustains the surfacewater flow year-round in the southern part of the catchment.

A hydrograph of the discharge of DR2 near the catchment outflow (site W13) shows the influence of the annual irrigation cycle (fig. 4). Ground-water levels measured in wells throughout the catchment were consistently higher than the stage of the water in DR2, indicating that ground water flowed toward DR2 at all times. During the nonirrigation season (mid-October through mid-March), base flow in the stream is sustained by ground water, most of which originated as infiltrating irrigation within and upgradient of the DR2 basin. During the irrigation season (mid-March through midOctober), discharge at site W13 increased two- to threefold. The shape of the annual discharge hydrograph is defined by the controlled application of irrigation water, and because of the absence of major precipitation events, short-term variation in stream flow is small and occurs predominantly during the irrigation season, driven by crop demands and agricultural practices. 


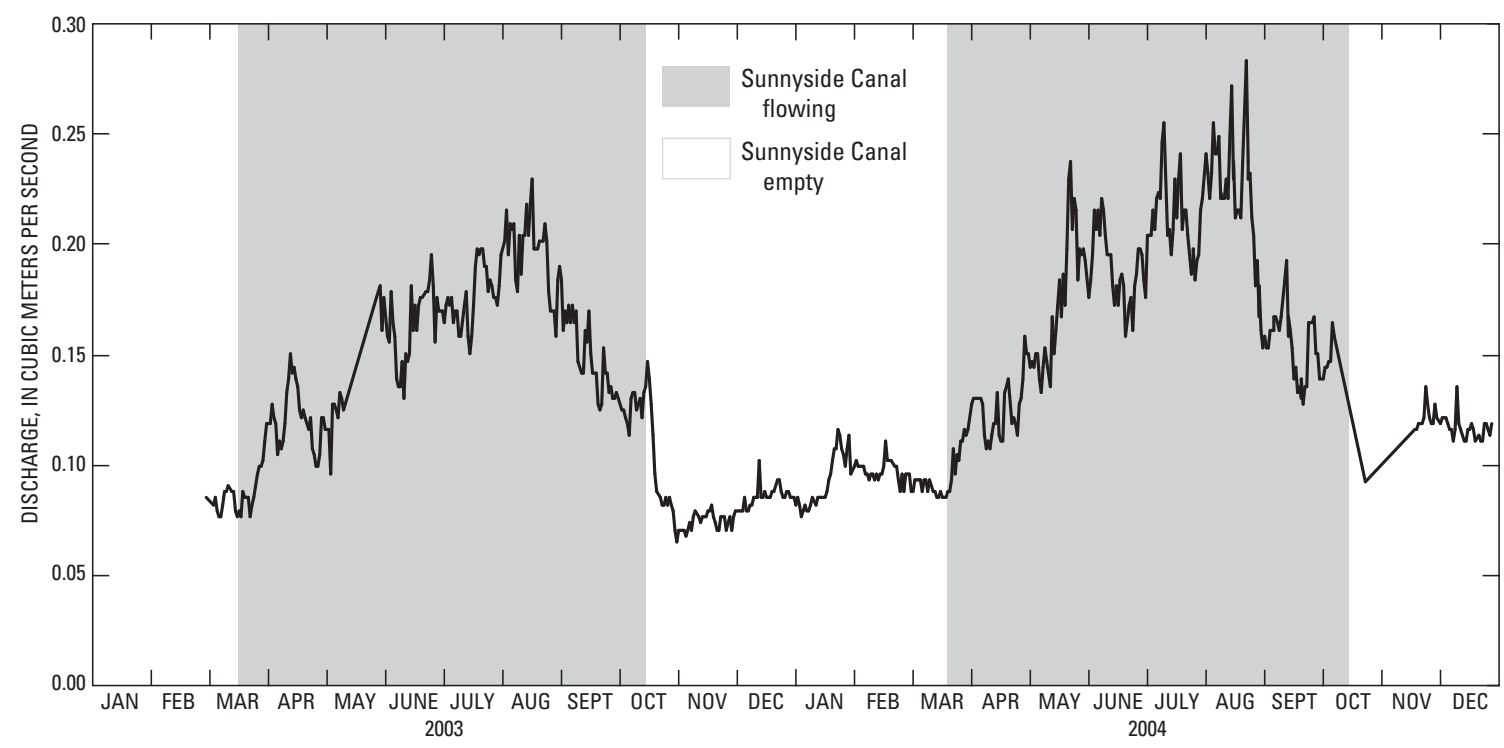

Figure 4. Discharge for the DR2 Catchment surface-water outflow (site W13), Yakima River basin, Washington.

A conceptual model of subsurface flow in the DR2 catchment was developed on the basis of several lines of evidence, including ground-water levels, ground-water age estimates, the isotopic composition of water from selected sites, visual observations of flow in the surface drainage network, and results of numerical ground-water modeling and flow-path simulations (Leon J. Kauffman, U.S. Geological Survey, written commun., 2006). In this conceptualization, regional ground-water generally flows from north to south, but the local shallow system is more complex, consisting of small-scale subsystems driven by individual irrigation events and constrained by local topography and the extensive system of artificial drains (both surface and buried) that intercept shallow ground water and route it toward the surface-water drainage network (fig. 5). While the drain system promotes lateral flow to the stream, upward flux of deeper ground water through the streambed is limited, especially in the southern part of the catchment, by low-permeability streambed material. At the streambed transects, permeabilities ranging from $10^{-5}$ to $10^{-6} \mathrm{~m} / \mathrm{s}$ were estimated by temperature flux modeling (Essaid and others, 2008). Finally, a considerable volume of deep ground water flows out of the catchment as ground water (fig. 3), not discharging to the surface system until it reaches Granger Drain or the Yakima River (fig. 1).

Water-level measurements in wells in the northern part of the catchment - at sites W24 and W25 (fig. 1) - consistently showed a downward gradient (fig. 6B-C). Several lines of evidence indicate that a downward vertical gradient also exists in the ground-water system near well W30. Although a second well at a different depth was not available to confirm it, the seasonal fluctuations in the ground-water level and temperature at W30 were similar to those in W24 and W25. In addition, age tracers ( $\mathrm{SF}_{6}$ and $\mathrm{CFCs}$ ) in water from W30 were consistent with concentrations in the atmosphere in the early 1980s, indicating little mixing of this water with either older or younger water. Finally, there are no surface water discharge zones in the area. All these factors are consistent with predominately downward vertical movement of ground water.

Ground-water levels in the northern part of the catchment fluctuated on an annual cycle (fig. $7 A-C$ ), with the lowest levels occurring in late spring to early summer, and the highest levels occurring in late summer to early fall in a delayed response to irrigation. The annual range in water levels in these wells was $1-2 \mathrm{~m}$. This range is larger than was observed downgradient because the relatively thick unsaturated zone in the upper catchment prevents discharge to surfacewater outlets. Although the water table rises and falls in the upper portion of the catchment in response to infiltrating irrigation water, the response to individual irrigation events is dampened during the movement of the water through the thick unsaturated zone. Water temperatures in these wells also fluctuated on an annual cycle, but the seasonal variation was less than $1{ }^{\circ} \mathrm{C}$ (fig. $7 \mathrm{~A}-\mathrm{C}$ ), again due to the insulating and moderating influence of a relatively thick unsaturated zone.

In the southern part of the catchment, at sites W20 and W21 (fig. 1), as well as at neighboring site W32, groundwater levels showed an upward gradient (fig. 6F-H) . At these wells, water levels sometimes fluctuated on a daily basis, but showed no seasonal pattern (fig. 7D-E). The daily fluctuations were likely a response to individual irrigation events and 


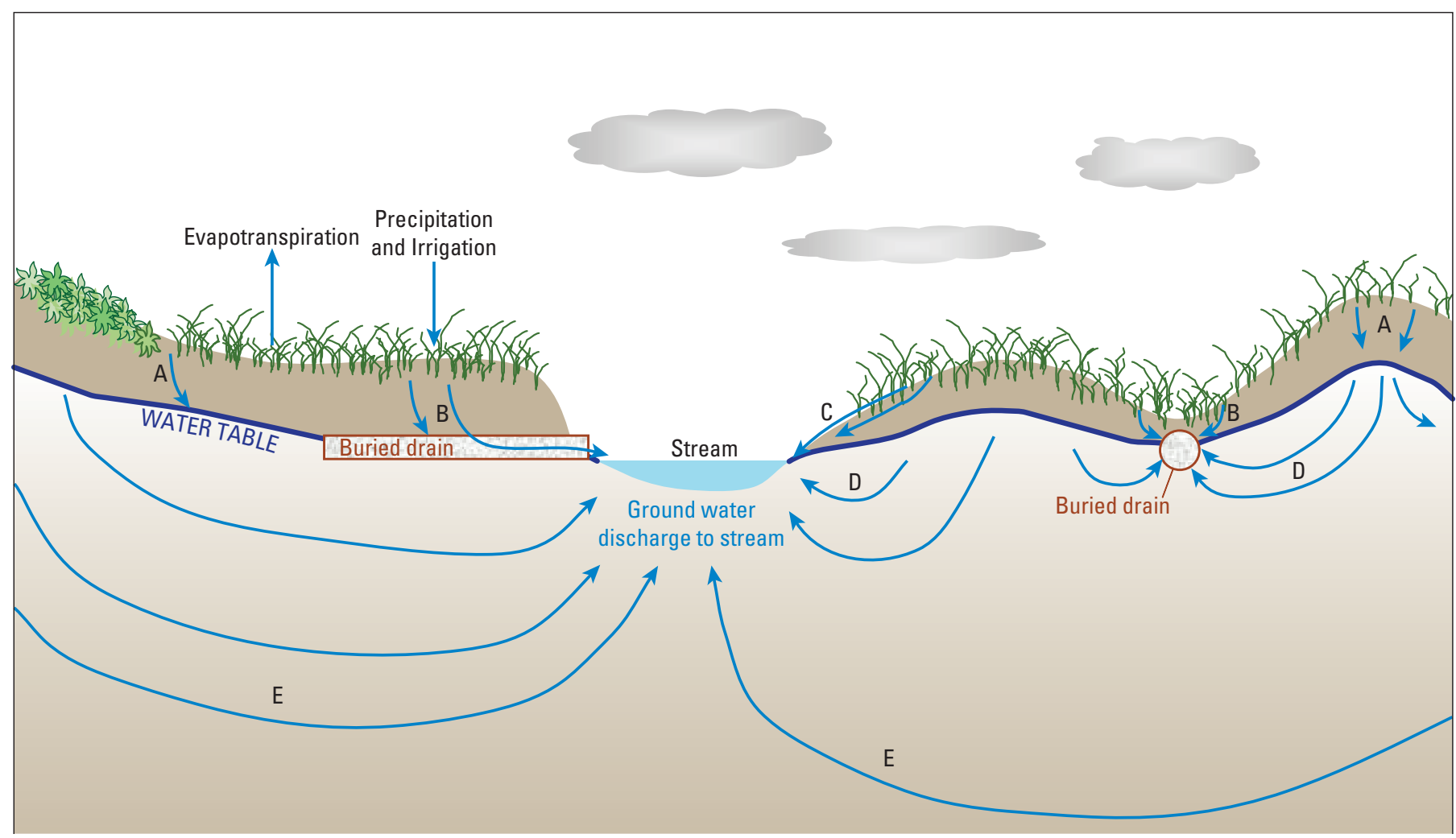

Figure 5. Conceptualization of the hydrology of the DR2 catchment, Yakima River basin, Washington. (Near surface flow paths include $(A)$ infiltration and percolation to the water table, $(B)$ infiltration and interception by buried drains, and $(C)$ overland/near-surface flow. Ground-water follows $(D)$ shallow, short flow paths and $(E)$ deep, longer flow paths.)

(or) evapotranspiration, evident in these wells because the water table in this part of the catchment is relatively shallow. The shallow water table also was reflected in the water temperatures in these wells. Relative to those in the upper catchment, temperatures varied considerably, with summer maximum temperatures approximately $5^{\circ} \mathrm{C}$ greater than winter minimum temperatures (fig. 7).

Site W23 is in the midcatchment, where the predominant direction of vertical flow in the ground-water system transitions from downward to upward. Comparing levels measured in sites W23p and W23q (fig. 8) shows that the vertical gradient is generally upward, but periodically reverses to downward during the irrigation season. Data from this well demonstrate the response of the ground-water system to individual irrigation events and illustrate changes in the flow system in response to a change in irrigation method. Rill irrigation was used near these wells during 2003. In 2004, the farmland immediately upgradient of these wells was converted to sprinkler irrigation. During 2003, the frequency of head reversals was greater and the magnitudes of downward gradients were greater. Water levels in these wells also illustrate the general seasonal effect of irrigation - the vertical gradient diminished when canal deliveries ceased in mid-October 2003, and approached zero by the end of the end of the winter. Finally, corresponding increases in water temperature (fig. 8) indicate that gradient reversals in the ground water at site W23 are not due simply to a pressure response, but rather to warmer water from the surface or near surface actually being transported into the saturated zone and raising the local water table.

Estimated dates of ground-water recharge, based on interpretation of the $\mathrm{CFC}, \mathrm{SF}_{6}$, and ${ }^{3} \mathrm{H}$ data (Green and others, 2008), generally are consistent with the conceptual model of subsurface flow developed from ground-water levels (fig. 9). Data from wells in the midcatchment (sites W23 and W24) suggest that this is a mixing zone of waters recharged at different times. Age tracers from site W24q are consistent with this water being a mixture of water recharged around 2000 and water recharged around 1970. Age-tracer data from site W23q are consistent with water in this well being predominantly water recharged around 1980 but indicate contributions from water recharged prior to the mid-1960s. These mixtures are consistent with vertical mixing that would result from periodic vertical gradient reversals in the midcatchment and also with the conceptual model of a dynamic shallow flow system highly influenced by irrigation applications and drainage modification sitting atop a reservoir of considerably older, slower moving water. Throughout the catchment, water from the shallow water-table wells contained at least a component of recently recharged water, reflecting the movement of excess irrigation water into the underlying saturated zone. 

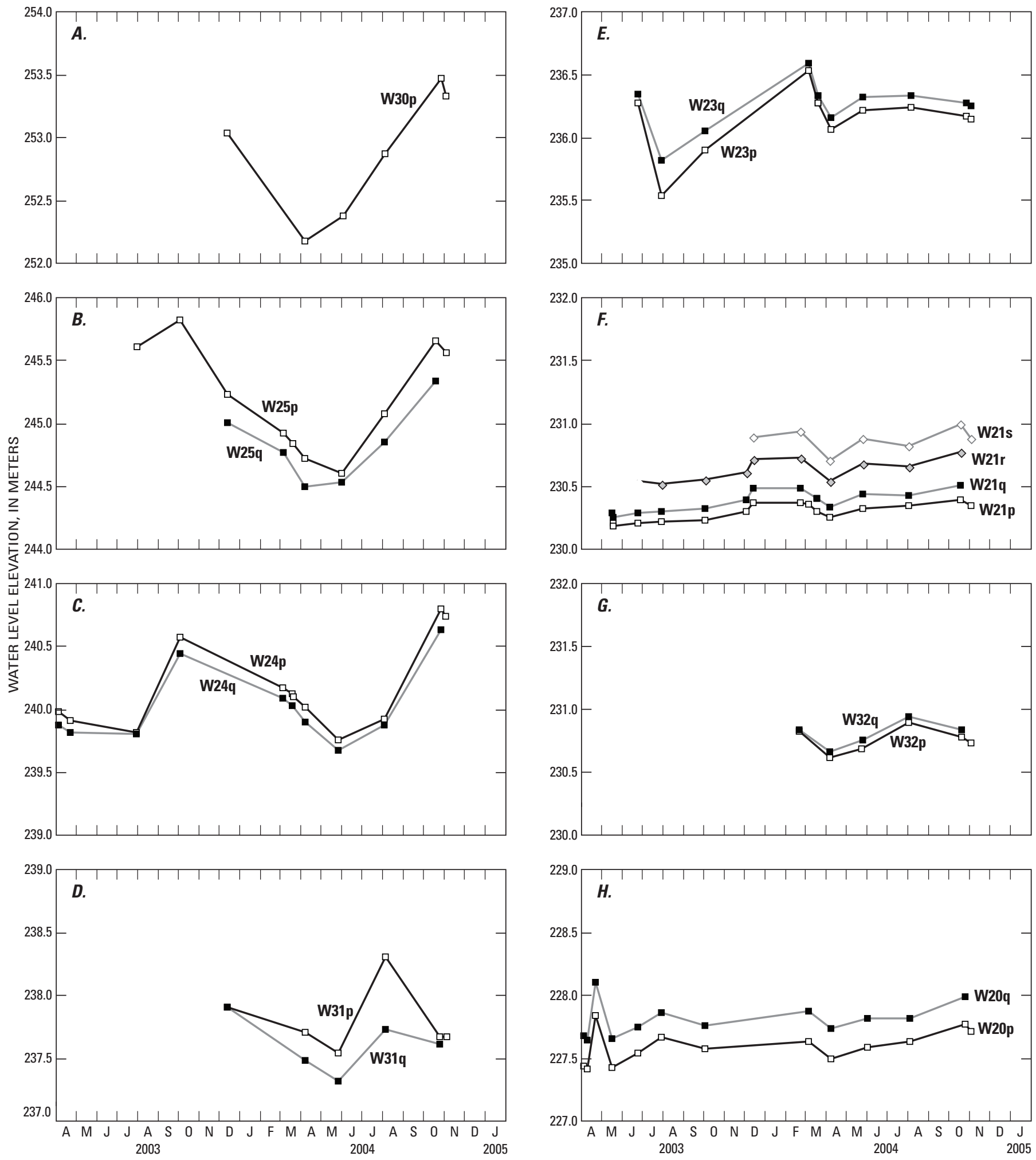

Figure 6. Water levels in well pairs in the DR2 catchment, Yakima River basin, Washington. (The single well at site W30 is shown for comparison purposes only; suffix $p$ indicates the shallowest well at each site; $q$, $r$, and s indicate increasingly deeper wells, respectively.) 

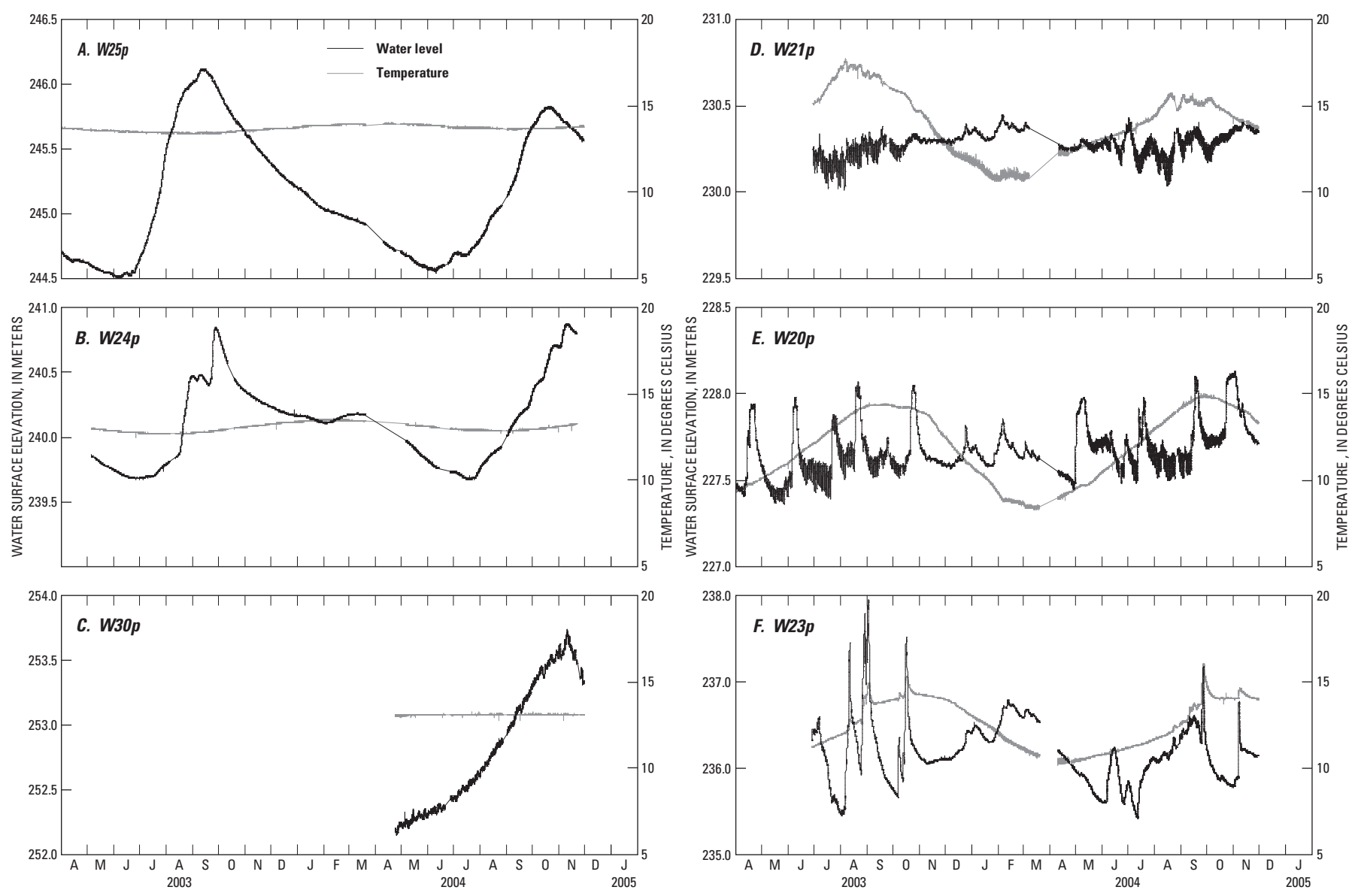

Figure 7. Water levels and water temperatures in ground water in the DR2 catchment, Yakima River basin, Washington.

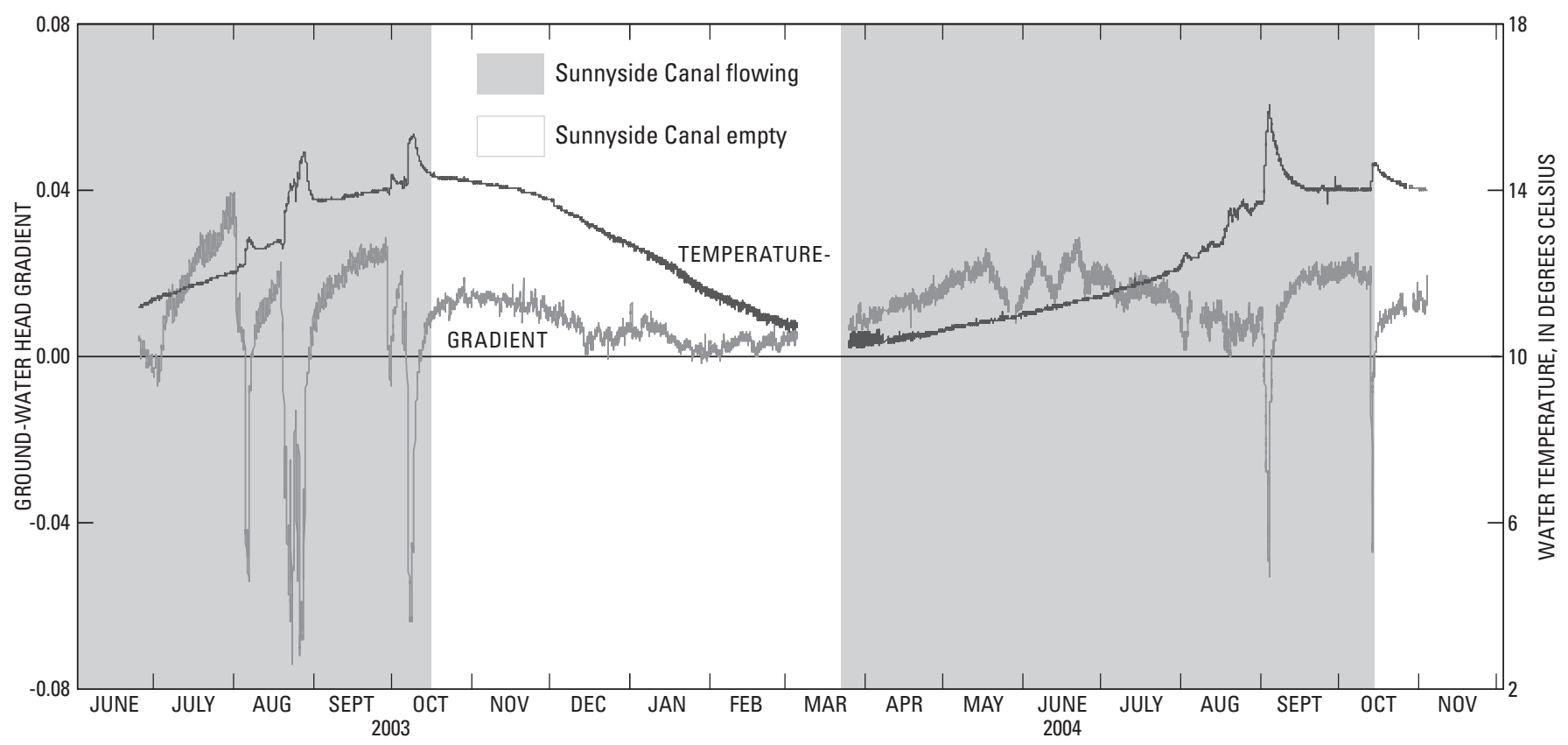

Figure 8. Ground-water head gradient (black line) and temperature (grey line) at site W23, DR2 catchment, Yakima River basin, Washington. (A positive gradient indicates upward flow.) 


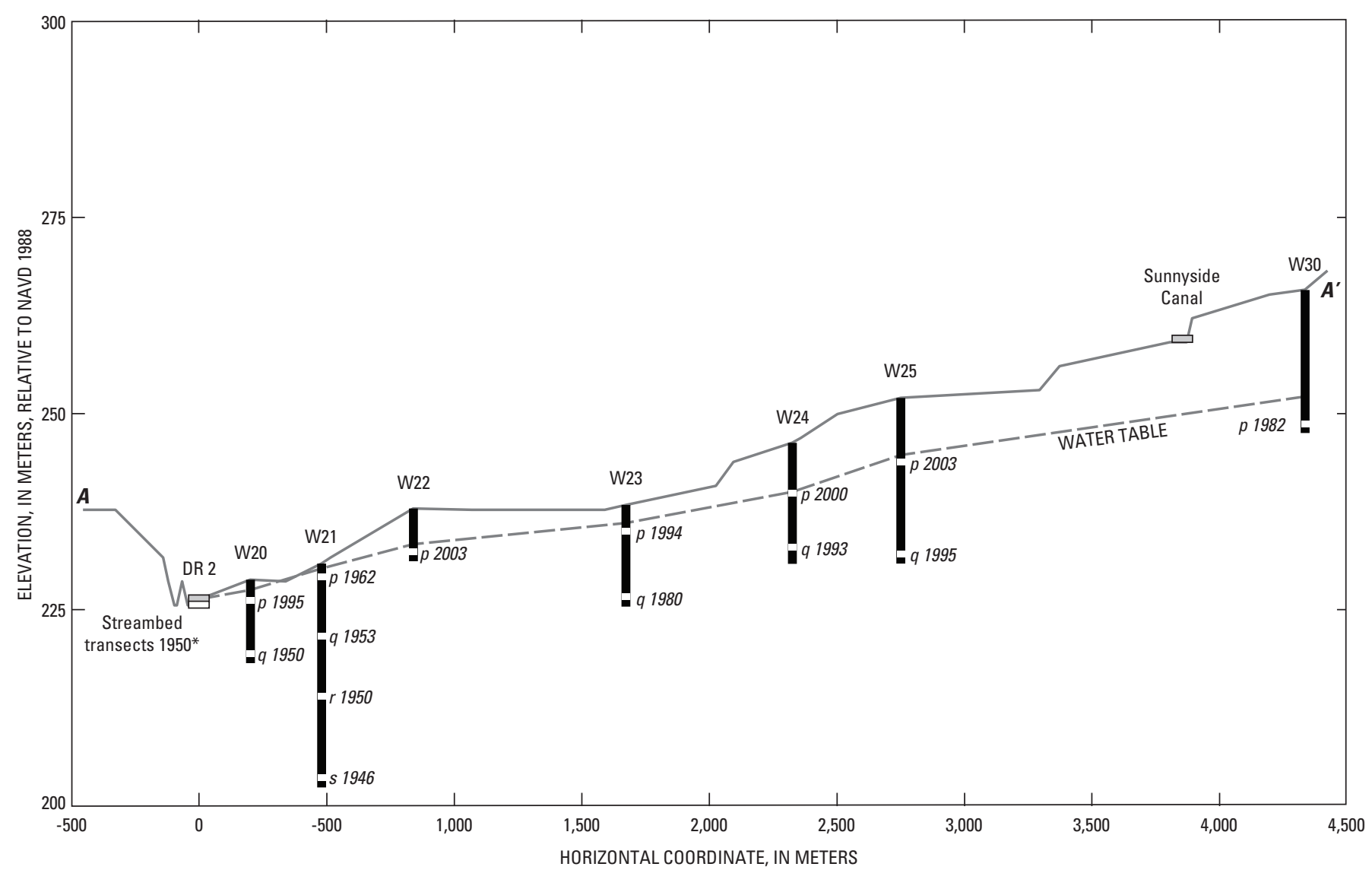

Figure 9. Estimated ground-water recharge dates in the DR2 catchment, Yakima River basin, Washington. ( ${ }^{*}$ Estimated recharge date for seven streambed samples - two from the downstream transect and five from the upstream transect; see figure 1 for location of section $A-A^{\prime}$.)

The effects of artificially enhanced drainage in the southern part of this system can be seen by comparing the hydrographs of wells at sites W20p and W21p (fig. 7D-E). Short-term fluctuations in the water level at W20p show the effects of individual irrigation events in the adjacent pasture. By contrast, the water level at $\mathrm{W} 21 \mathrm{p}$ shows little variation, likely due to the damping effect of the shallow drain that surrounds this field and efficiently shunts excess irrigation to the surface-water system. Age-tracer data from W21p (fig. 9), which indicate that the shallow ground water here was not recently recharged, support this reasoning.

The stable isotopes of water from selected sites (fig. 10) also corroborate the conceptual model of flow in DR2. From late April to late August, the canal water becomes enriched in the heavier isotopes, oxygen-18 $\left({ }^{18} \mathrm{O}\right)$ and deuterium $\left({ }^{2} \mathrm{H}\right)$. Samples from W23p and W24p are isotopically indistinguishable from late season canal water, consistent with this shallow ground water being recently applied irrigation. W21s is somewhat more depleted in the heavy isotopes than the other wells sampled. This was the deepest and oldest ground water sampled (fig. 9), and this isotopic signature likely reflects a contribution from older, regional ground water. W25p is slightly enriched in the heavier isotopes relative to other samples; these isotope values suggest a source of water similar to other nearby ground water (such as that from W23p, W24p, and W25q) that has undergone additional evaporative losses.

The isotopic composition of streambed water from W63c differs considerably from all other water sampled. That sample is much more depleted in ${ }^{2} \mathrm{H}$ and ${ }^{18} \mathrm{O}$ than other water samples collected for this study, indicating that the shallow subsurface water near the catchment outlet is derived from a different source than other water sampled. Particle-tracking simulations suggest that the deepest, longest ground-water flow paths in the catchment discharge near W63c and that water from the streambed there includes a significant component of the oldest ground water in the catchment. Tritium data (not shown) for the three streambed sites sampled (W51c, W55b, and W64c) also indicate that water from these sites includes a substantial component of relatively old water, recharged more than 50 years ago.

The isotopic signature of water from the DR2 drain (W13) is similar to that of shallow ground water and water from the Sunnyside Canal, and the shift in isotopic signature from spring to summer in water from the drain mimics that seen in water from the canal. During both seasons, however, the water from DR2 drain was slightly depleted in the heavier isotopes relative to corresponding canal water samples, which is consistent with a small contribution from deep ground water (fig. 10). 


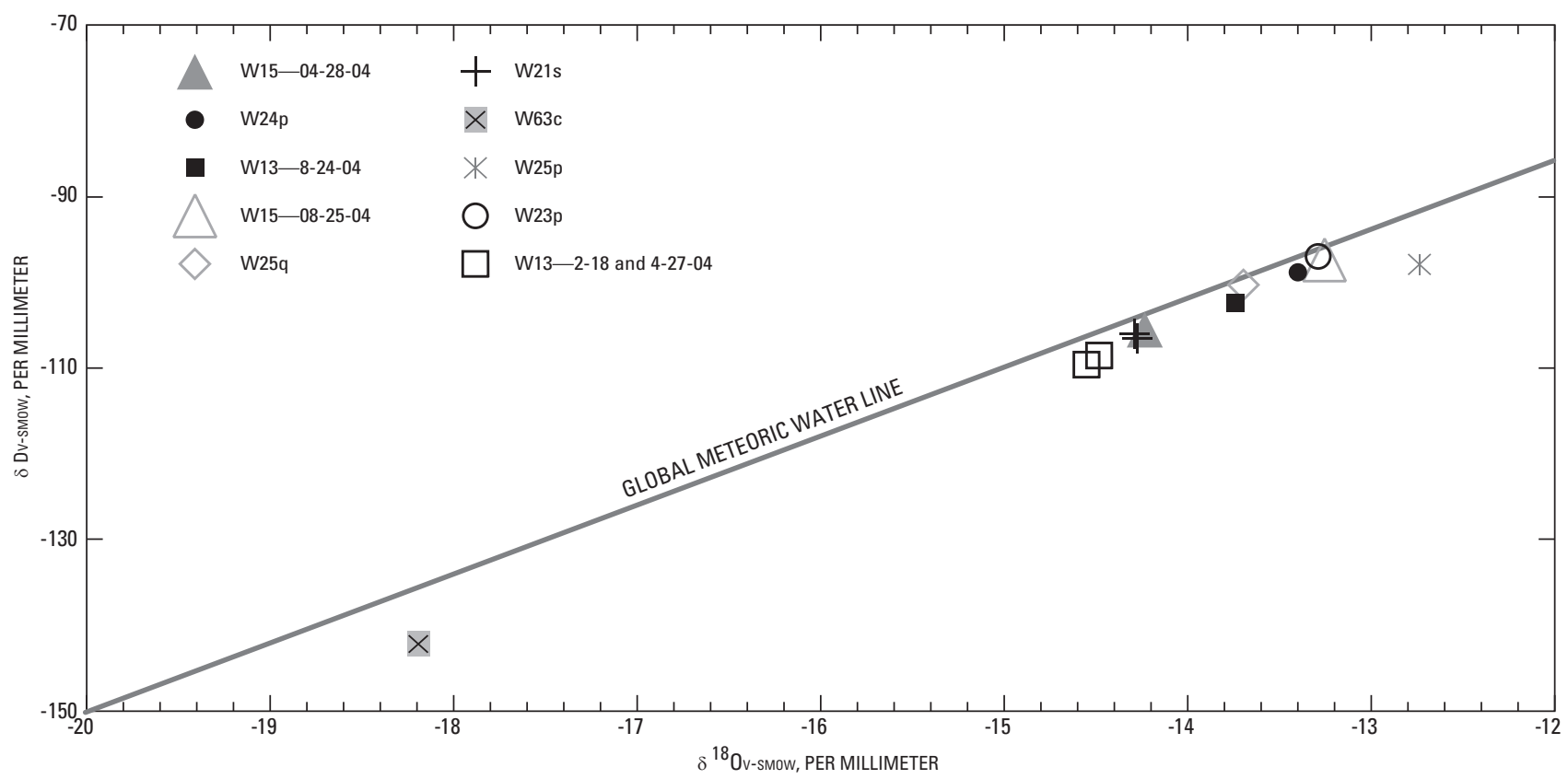

Figure 10. Abundance of deuterium and oxygen-18 in water samples from the DR2 catchment, Yakima River basin, Washington.

\section{Water Chemistry}

Water chemistry data were collected at sites representing several environmental compartments (fig. 1). Analysis of samples from the Sunnyside Canal (W15) indicates the composition of imported irrigation water prior to distribution in the catchment. Samples from a field drain (W42) provide an example of the chemistry of excess irrigation runoff from a single field - in this case likely a mixture of overland flow and shallow soil drainage. Samples from wells (W20-W32) reveal the characteristics of ground water at various locations throughout the catchment, both near the water table and somewhat deeper, but all in the shallow part of the flow system. Sites in two streambed transects in the lower reach of DR2 (W51-W65) show the composition of ground water just prior to its discharge into the stream. Finally, samples from near the DR2 catchment outlet (W13) reveal the composition of surface-water discharge from the catchment.

As discussed earlier, virtually all of the surface-water discharge from the catchment can be attributed to excess irrigation. As this water passes through the catchment, its chemistry is altered by biochemical and geochemical reactions at the land surface, in the soil, and in the ground-water system.

Fertilizers and other soil amendments used in the DR2 catchment are important sources of $\mathrm{N}$ and $\mathrm{P}$, as well as potassium, calcium, magnesium, sodium, chloride, and sulfur. Cattle manure is applied as a fertilizer and soil amendment to many crops in the area either as liquid slurry or as solids, and, based on the classification scheme of Kendall (1998), ${ }^{15} \mathrm{~N}$ and ${ }^{18} \mathrm{O}$ isotopes of nitrate (fig. 11) suggest that manure may be a major source of the nitrate measured in waters throughout the catchment.

Mineralogical analyses of subsurface material (sampled during well drilling) show its composition is predominantly quartz, plagioclase, potassium feldspar, and calcite. Through weathering processes, these minerals are abundant sources of silica, calcium, sodium, and potassium. Dolomite and hornblende, which contain magnesium, also are common in the area. Finally, smectite, which has a high cation-exchange capacity, was an important component of the colloidal fraction of most samples analyzed, and likely plays a role in water chemistry.

Comparing the chemistry of water from a number of environmental compartments and locations provides insight into the processes that affect the quality of water discharging from this catchment:

Irrigation water--Water from the Sunnyside Canal had the lowest concentrations of major solutes and dissolved nutrients of any compartment sampled (figs. 12-13). Because the canal is the major source of water to the catchment, the chemistry of water from other environmental compartments gives an indication of how this canal water is altered as it passes through the catchment. 


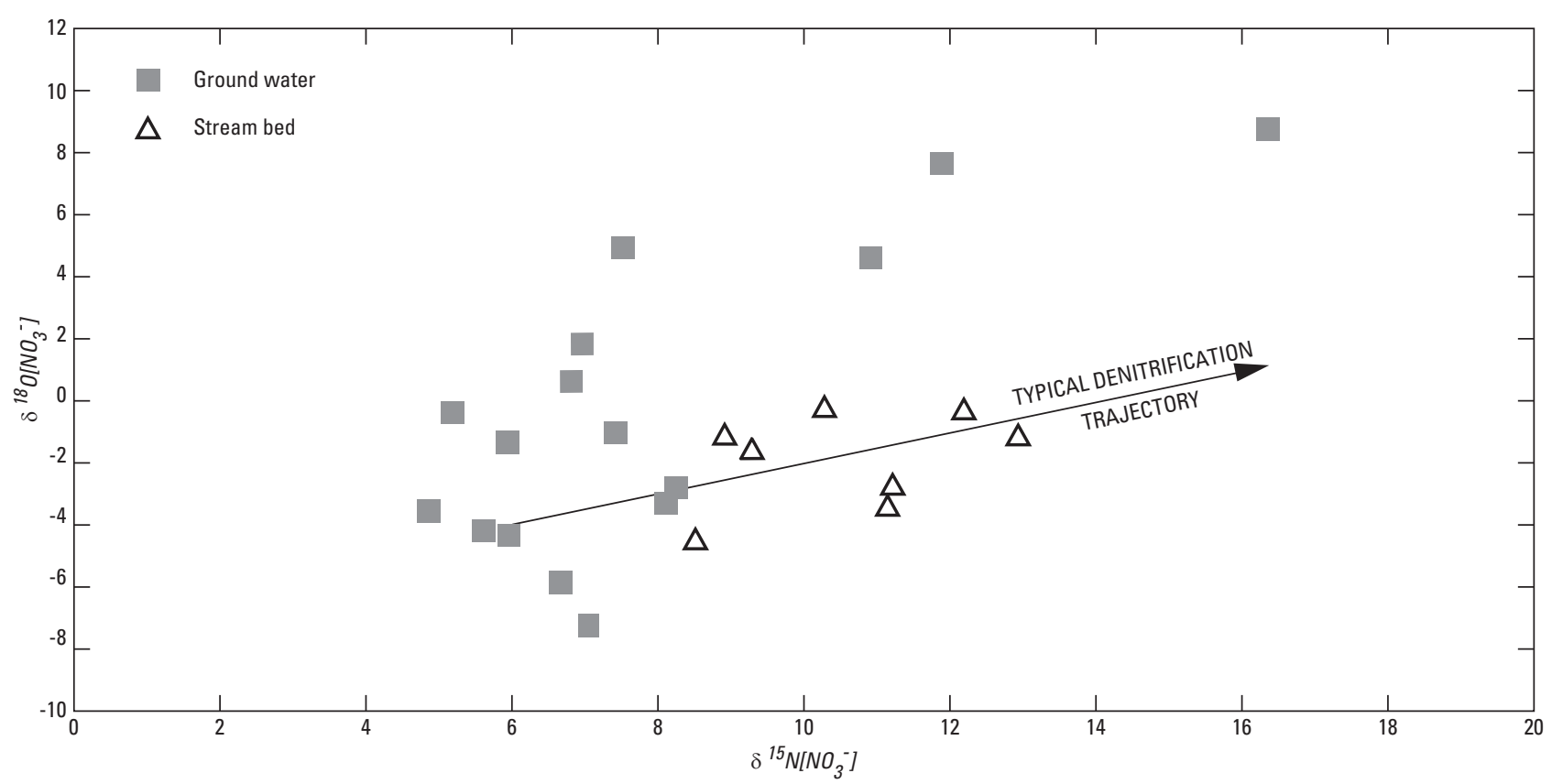

Figure 11. Abundances of oxygen-18 and nitrogen-15 in nitrate in water samples from the DR2 catchment, Yakima River basin, Washington.

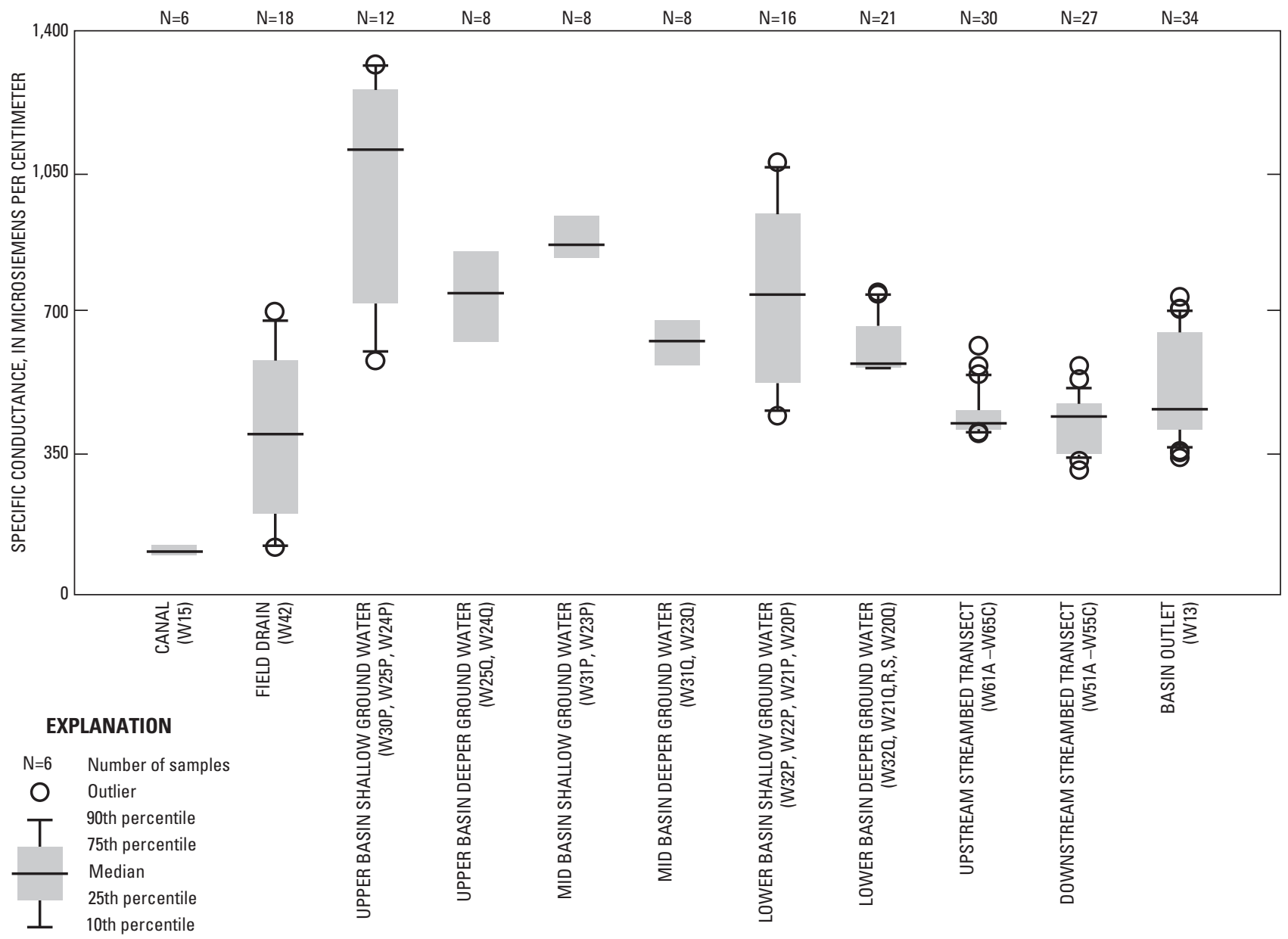

Figure 12. Distribution of specific conductance of water samples from the DR2 catchment, Yakima River basin, Washington. 

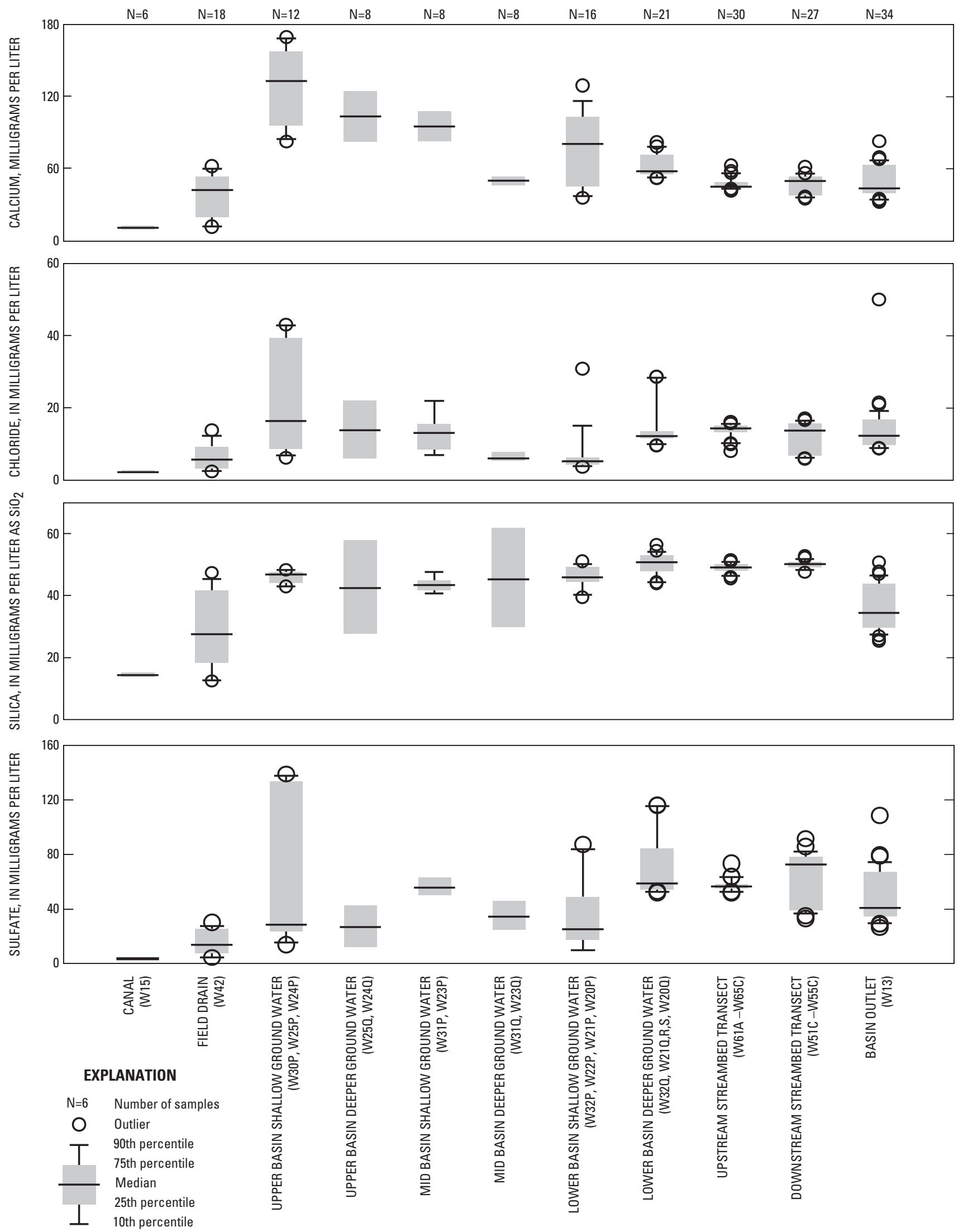

Figure 13. Distribution of concentrations of major solutes in water samples from the DR2 catchment, Yakima River basin, Washington. 
Field drain.-The field drain flowed year-round, and both the discharge and chemical character of the water fluctuated with time. During winter, the major solute chemistry of water from the drain was similar to that of water from nearby well W21p, suggesting that winter flow in the drain was discharging ground water. Over the course of the irrigation season, the chemistry of the water from the field drain varied considerably (for example, $\mathrm{N}$ ranges from less than 1 to more than $23 \mathrm{mg} / \mathrm{L}$; silica ranges from 13 to $47 \mathrm{mg} / \mathrm{L}$ ), suggesting changing contributions from several sources, including ground water, shallow soil water, and irrigation tailwater. This composite discharge from the drain consistently had higher concentrations of major solutes and dissolved nutrients than water from the canal (figs. 12-13). Concentrations of the major solutes calcium, magnesium, potassium, sodium, chloride, sulfate, and silica, were inversely related to drain flow rates $\left(\mathrm{R}^{2}=0.4-0.6\right)$. Concentrations of nitrate also tended to be lower at higher flow rates $\left(\mathrm{R}^{2}=0.3\right)$, but although the highest concentrations of soluble reactive $\mathrm{P}$ (SRP) were measured during low-flow conditions, there was no apparent relationship between SRP and flow $\left(\mathrm{R}^{2}<0.1\right)$. The major solutes, as well as nitrate, also were inversely correlated with concentrations of suspended sediment in water from the field drain, though relationships were weaker than for discharge $\left(\mathrm{R}^{2}=0.2-0.3\right)$. The highest concentrations of SRP also occurred when concentrations of suspended sediment were low, but again, the relationship between SRP and suspended sediment was not significant $\left(\mathrm{R}^{2}<0.1\right)$. Data from Ebbert and others (2003) and Fuhrer and others (2004) point to a relatively constant contribution of SRP from ground water in this area. The poor correlation between SRP and suspended sediment may reflect differing mixtures of shallow ground water, soil water, and overland flow, in which concentrations of suspended sediment and dissolved constituents can vary considerably, depending on the amount of time since the field was last tilled and the timing of sample collection relative to individual irrigation events. Longer contact times between soil and water at lower flow rates may also be a contributing factor to the patterns observed. Durand and others (1999) noted that increased depth and velocity of overland flow (such as would occur during times of high drain discharge) tended to decrease concentrations of solutes.

Ground water.-The chemistry of the water from most individual wells varied little over the course of the study, but differences in water chemistry among wells were substantial. Relative to water from the canal and field drain, ground water typically had higher concentrations of major solutes. Although concentrations varied considerably among wells, water from the shallow wells typically had higher concentrations than that from deeper wells, suggesting that water-rock interactions in the subsurface may be a less important source of the major solutes than near-surface sources such as cattle manure, other fertilizers and soil amendments, and weathered soil.
The highest concentrations of $\mathrm{N}$ in ground water, which was present predominantly as nitrate, generally were detected in water from wells in the upper catchment (sites $\mathrm{W} 24, \mathrm{~W} 25$, and W30). Concentrations of $\mathrm{N}$ in water samples collected from well W25p consistently exceeded $70 \mathrm{mg} / \mathrm{L}$. This is probably the result of a complex interaction of factors, including the local ground-water flow system and local agricultural practices. Site W25 is at a local topographic high, and subsurface flow is likely to be directed downward rather than laterally. The very recent recharge date calculated for W25p (fig. 9) is consistent with relatively rapid, direct downward flow near the water table. Furthermore, this well is in an area where cattle manure, a potential source of considerable $\mathrm{N}$, was applied liberally.

Concentrations of excess dissolved $\mathrm{N}_{2}$ in water from most wells was low (table 1). Dissolved $\mathrm{N}_{2}$ in excess of the concentration achieved through equilibration with the atmosphere plus excess air (Dunkle and others, 1993) indicates that nitrate previously present in the water has undergone denitrification - the process by which nitrate is transformed into $\mathrm{N}_{2}$. Thus, low concentrations of excess dissolved $\mathrm{N}_{2}$ in water from most wells indicate that denitrification is not a major process in this ground-water system. Green and others (2008) present the details of excess dissolved $\mathrm{N}_{2}$ calculations and discuss the limited denitrification in this ground-water system.

Streambed transects.- Similar to the findings for ground water, the chemistry of water from individual sites within the streambed transects varied little over the course of the study. However, the range in the data from each transect (figs. 1, $\underline{11}-14$, table 1) shows that water chemistry differs over very small distances (tens of centimeters) in this system. Some of these differences may result from spatial variations in the composition of the streambed, but the variability observed also suggests that flow paths from different source areas are converging to discharge into this lower reach of DR2, and provides insight into differences between the chemistry of relatively deep ground water that discharges upward into the stream and that of the shallow ground-water system that flows laterally into the stream.

Compared to the ground water sampled, water from both streambed transects tended to have lower specific conductance and alkalinity, as well as lower concentrations of calcium, magnesium, and sodium (fig. 12). In contrast, concentrations of potassium, chloride, silica, and SRP tended to be similar to those measured in ground water (figs. 12-13). These conditions indicate that differences between water in the streambed and ground water were not likely due to simple geochemical processing or dilution (from unapplied irrigation water, for example), but suggests that a component of the streambed water comes from a source distinct from other ground water sampled. We hypothesize that this source is relatively old ground water discharging from the deep, long ground-water flow paths mentioned previously. 
Table 1. Excess nitrogen gas $\left(\mathrm{N}_{2}\right)$ measured in the DR2 catchment, Yakima River basin, Washington.

[Site locations are shown in figure 1. Suffix p indicates the shallowest well at each site; q, r, and s indicate increasingly deeper wells, respectively]

\begin{tabular}{|c|c|c|c|c|}
\hline \multirow{2}{*}{$\begin{array}{c}\text { Site } \\
\text { identification } \\
\text { No. }\end{array}$} & \multicolumn{3}{|c|}{$\begin{array}{c}\text { Concentration } \\
\text { (milligrams per liter) }\end{array}$} & \multirow{2}{*}{$\begin{array}{c}\text { Number } \\
\text { of } \\
\text { samples }\end{array}$} \\
\hline & Average & Minimum & Maximum & \\
\hline \multicolumn{5}{|c|}{ Ground water } \\
\hline W20p & 0.00 & 0.00 & 0.00 & 4 \\
\hline W20q & 2.93 & 2.84 & 3.00 & 4 \\
\hline W21p & 0.24 & 0.00 & 0.50 & 4 \\
\hline W21q & 0.00 & 0.00 & 0.00 & 4 \\
\hline W21r & 0.43 & 0.00 & 0.87 & 4 \\
\hline W21s & 0.18 & 0.00 & 0.38 & 4 \\
\hline W23p & 0.86 & 0.13 & 1.60 & 4 \\
\hline W23q & 2.03 & 0.90 & 3.10 & 4 \\
\hline $\mathrm{W} 24 \mathrm{p}$ & 0.29 & 0.22 & 0.36 & 2 \\
\hline $\mathrm{W} 24 \mathrm{q}$ & 0.02 & 0.00 & 0.04 & 2 \\
\hline $\mathrm{W} 25 \mathrm{p}$ & 0.35 & 0.25 & 0.45 & 2 \\
\hline W25q & 0.88 & 0.86 & 0.89 & 2 \\
\hline W30p & 0.69 & 0.42 & 0.94 & 4 \\
\hline W31p & 2.14 & 1.96 & 2.32 & 4 \\
\hline W31q & 0.00 & 0.00 & 0.00 & 4 \\
\hline W32p & 1.57 & 1.50 & 1.64 & 2 \\
\hline W32q & 0.00 & 0.00 & 0.00 & 4 \\
\hline \multicolumn{5}{|c|}{ Upstream streambed transect } \\
\hline W61b & 1.79 & 1.78 & 1.80 & 2 \\
\hline W61c & 2.84 & 2.80 & 2.88 & 2 \\
\hline W62b & 2.13 & 2.11 & 2.14 & 2 \\
\hline W62c & 3.19 & 3.18 & 3.20 & 2 \\
\hline W63a & 2.89 & 2.80 & 2.98 & 2 \\
\hline W63c & 2.93 & 2.89 & 2.97 & 2 \\
\hline W64a & 2.73 & 2.64 & 2.81 & 2 \\
\hline W64c & 3.25 & 3.17 & 3.34 & 2 \\
\hline \multicolumn{5}{|c|}{ Downstream streambed transect } \\
\hline W51a & 0.7 & 0.64 & 0.79 & 2 \\
\hline W51c & 1.7 & 1.61 & 1.79 & 2 \\
\hline W52b & 0.9 & 0.92 & 0.92 & 1 \\
\hline W53b & 1.4 & 1.31 & 1.47 & 2 \\
\hline W54a & 6.5 & 6.25 & 6.76 & 4 \\
\hline W55b & 1.0 & 0.90 & 1.02 & 2 \\
\hline
\end{tabular}

The concentrations of nitrate were lower in water from the streambed than in most ground water sampled (fig. 14). In water samples collected from the upstream transect, concentrations of excess $\mathrm{N}_{2}$ consistently exceeded $2.5 \mathrm{mg} / \mathrm{L}$, except at sites $\mathrm{W} 62 \mathrm{~b}$ and $\mathrm{W} 61 \mathrm{~b}$ (table 1). In water samples collected from the downstream transect, concentrations of excess $\mathrm{N}_{2}$ ranged from less than 1 to more than $6 \mathrm{mg} / \mathrm{L}$ (at site W54a). These data indicate that denitrification occurs in portions of the subsurface, but that conditions vary over very small distances. Values of ${ }^{18} \mathrm{O}$ and ${ }^{15} \mathrm{~N}$ isotopes from nitrate collected from the streambed also suggest that denitrification occurs in this zone (fig. 11). (Puckett and others [2008] provide further details on denitrification in the streambed.) Although several lines of evidence indicate that denitrification occurs in this zone, the effects on nitrate concentrations in surface water are limited by the small flux of water involved. Several factors combine to constrain water flux through the streambed. First, as mentioned earlier, the permeability of the streambed is low; second, irrigation flow during the growing season raises the water level in DR2, which reduces the gradient from ground water to the stream; and third, enhanced shallow drainage throughout the catchment shunts ground water laterally toward surface drains and effectively bypasses deeper flow paths.

Conditions at sites W61b and W62b, in the shallow, western part of the upstream transect indicate that lateral flow to the stream from a distinct water source occurs in this area. Concentrations of nitrate here were higher than in the rest of the transect, but concentrations of excess $\mathrm{N}_{2}$ were somewhat lower, suggesting a source of nitrate-rich water, but only limited progression of denitrification (due to either reduced capacity or shorter residence time). These two sites also had higher specific conductance, alkalinity, calcium, magnesium, potassium, sodium, and total $\mathrm{N}$ (mostly present as nitrate), and lower concentrations of chloride relative to other sites in the transect. Furthermore, water temperature near these sites was periodically colder than water deeper in the streambed (sites W61c and W62c) or water near the bottom of the overlying stream (fig. 15). These data indicate that colder water was flowing laterally toward the transect at middepth and provide evidence of lateral ground-water flow to the stream.

Catchment outlet.-The chemistry of the water at the catchment outlet is consistent with the water being a mixture of canal water, field drainage, ground water, and streambed discharge. Examining the chemistry at the catchment outlet in the context of the annual streamflow hydrograph provides further insight into processes in the catchment. Several of the major solutes (calcium, magnesium, sodium, chloride, sulfate, and silica) were inversely related to stream discharge. This pattern of lower concentrations during the irrigation season, when the highest discharges occurred in DR2, is illustrated by calcium and silica data (fig. 16A, B). Concentrations of nitrate in water from DR2 also were highest during the nonirrigation season, but concentrations during the irrigation season varied more than those of the major solutes (fig. 16C). In contrast, concentrations of SRP in the catchment outflow were highly variable, but generally increased during the irrigation season (fig. 16D). 


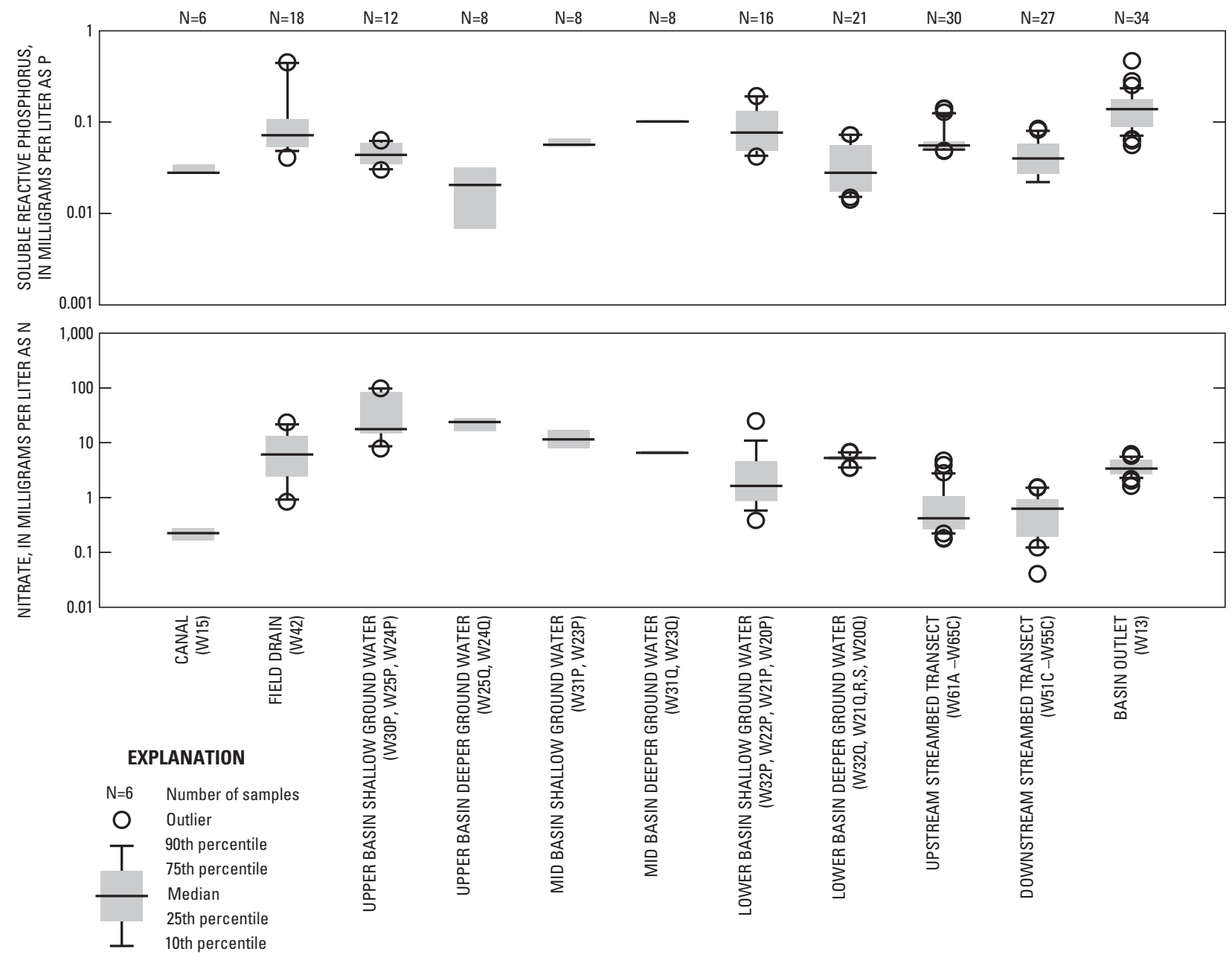

Figure 14. Distribution of concentrations of nitrate and soluble reactive phosphorus in water samples from the DR2 catchment, Yakima River basin, Washington.

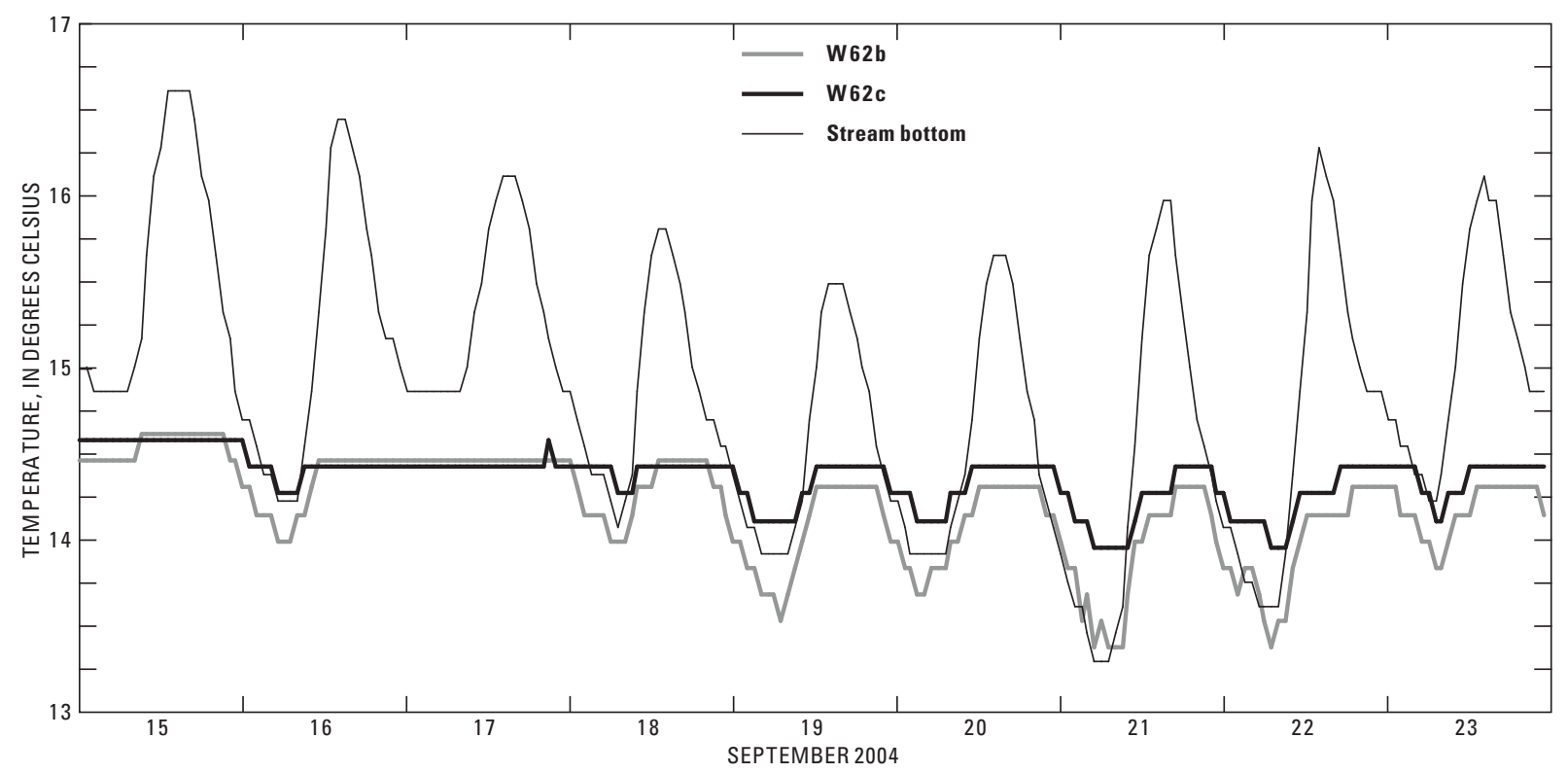

Figure 15. Vertical temperature profile measured in the streambed in the DR2 catchment, Yakima River basin, Washington, September 2004. 

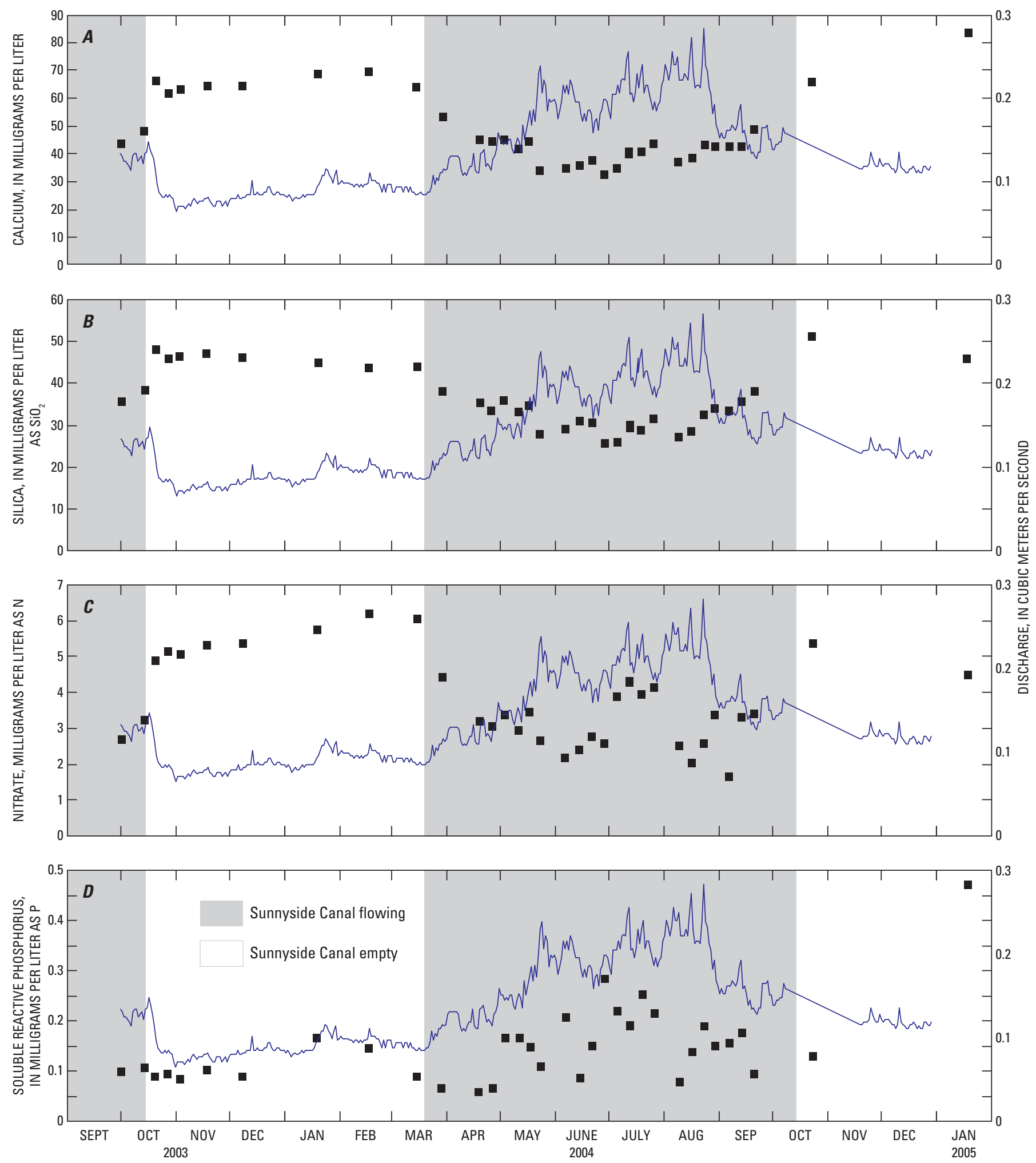

Figure 16. Concentrations of selected solutes (square symbols) and stream discharge (solid line) at the DR2 catchment outflow (site W13), Yakima River basin, Washington. 


\section{Inverse End-Member Mixing Analysis}

An inverse application of a simple end-member mixing analysis (EMMA) was used to help understand the differences in water chemistry between irrigation season and base-flow conditions in DR2 and to gain insight into the transport of agricultural chemicals in the catchment. As discussed in the previous sections, flow in DR2 was more than twice as high during the irrigation season than during base-flow conditions (in the winter), and the concentrations of most solutes were diluted during the higher-flow period. Of the major solutes and nutrients, only concentrations of SRP were higher during the irrigation season.

Conceptually, the water in DR2 during the irrigation season can be described as a mixture of ground-water base flow and a seasonal component, referred to here as "seasonal agricultural flow" (SAF). This conceptualization, modified from Domagalski and others (2008), can be expressed mathematically as

$$
Q_{i-D R 2}=Q_{i-b f}+Q_{S A F},
$$

where

$$
\begin{gathered}
Q_{i-D R 2} \text { is the median total discharge in DR2 } \\
\text { during the irrigation season, } \\
Q_{i-b f} \text { is ground-water base flow to the stream } \\
\text { during the irrigation season, and } \\
Q_{S A F} \text { is } \mathrm{SAF} \text {. }
\end{gathered}
$$

Comparing and contrasting the chemical characteristics of the hypothetical SAF with those of canal water gives insight into the composite effects of agriculture in the DR2 catchment on water quality.

For a conservative solute, the mass balance can be expressed as

$$
(Q C)_{i-D R 2}=(Q C)_{i-b f}+(Q C)_{S A F},
$$

where $C_{i-D R 2}, C_{i-b f}$, and $C_{S A F}$ are the median irrigation season concentrations of the solute in DR2, ground-water base flow, and SAF, respectively. Combining equations 1 and 2 and solving for $C_{S A F}$ yields

$$
C_{S A F}=\frac{(Q C)_{i-D R 2}-(Q C)_{i-b f}}{Q_{i-D R 2}-Q_{i-b f}}
$$

To solve this equation for individual solutes, the median discharge and concentrations of solutes measured at site W13 between mid-June and mid-September 2004 were used to approximate $Q_{i-D R 2}$ and $C_{i-D R 2}$. Hydraulic head data collected in the stream and in nearby ground water (fig. 7) showed that the average hydraulic gradient from ground water toward DR2 during the irrigation season was only about 80 percent of the gradient measured during the nonirrigation season. On the basis of these data, $Q_{i-b f}$ was approximated as 80 percent of the median discharge measured at site W13 during the nonirrigation season, from mid-October 2003 through mid-March 2004. Finally, making the assumption that the concentrations of solutes in base flow were similar during the irrigation and nonirrigation seasons, the medians of solute concentrations measured at site W13 between mid-October 2003 and mid-March 2004 were used to approximate $C_{i-b f}$.

The composition of SAF (table 2), calculated on the basis of equation 3 , serves as a tool for understanding source and transport processes in the DR2 catchment. Conceptually, $\mathrm{SAF}$ is a hypothetical composite of excess irrigation water and includes system spill (water that is transported directly from the irrigation delivery system to the surface-drainage system, without being released to the landscape), tailwater, overland flow, and applied irrigation water that infiltrates and then travels by way of shallow, short subsurface flow paths (subsurface drains, for example) to the surface-water system without being incorporated into the ground-water system. $\mathrm{SAF}$ is, therefore, water from the canal delivery system that passes through the catchment into DR2 during a single growing season. Comparison of the chemical characteristics of this hypothetical water to those of canal water provides insight into the net composite effect of current agriculture on water quality in the DR2 catchment. Furthermore, because nearly all groundwater base flow in the catchment can be attributed to irrigation over the past century (Payne and others, 2007), differences between SAF and base flow are attributable to changes that result from passage through the subsurface and (or) changes in agricultural practices over time. Finally, a comparison of SAF characteristics to those of water from the field drain enables a further understanding of how closely the net effect of processes in the single field sampled approximates the net effect of processes in the catchment as a whole.

SAF compared to canal water and base flow.Calculated concentrations of most solutes in the hypothetical SAF were intermediate between concentrations measured in water from the canal and those measured in water from DR2 during base-flow conditions (table 2). For several major solutes (calcium, magnesium, potassium, sodium, and silica), concentrations calculated for SAF were two to four times greater than concentrations in canal water, but only about 40-50 percent of the concentrations measured in base flow samples (fig. 17). These differences suggest that excess irrigation water picks up a considerable load of solutes as it travels through the catchment, even when following the relatively rapid surface and near-surface transport pathways postulated for SAF. However, subsurface flow paths that discharge as base flow are responsible for the greatest 
Table 2. Composition of surface flow-system components during the irrigation season in the DR2 catchment, Yakima River basin, Washington.

[Catchment surface-water outflow: median concentrations measured in DR2 (site W13) from mid-June through mid-September 2004. Base flow: median concentrations measured in DR2 site (W13) from mid-October 2003 through mid-March 2004. Canal: median concentrations measured in Sunnyside Canal (site W15) from mid-June through mid-September 2004. Field drain: median concentrations measured in the field drain (site W42) from mid-June through midSeptember 2004. SAF: hypothetical SAF calculated using equation 3. Abbreviations: $\mathrm{SAF}$, seasonal agricultural flow; $\mathrm{SiO}_{2}$, silicon dioxide; $\mathrm{m}^{3} / \mathrm{s}$, cubic meter per second; $\mu \mathrm{S} / \mathrm{cm}$, microsiemen per centimeter; $\mathrm{mg} / \mathrm{L}$, milligram per liter; na, not applicable]

\begin{tabular}{|c|c|c|c|c|c|c|}
\hline & Units & $\begin{array}{c}\text { Catchment } \\
\text { surface-water } \\
\text { outflow }\end{array}$ & Base flow & Canal & Field drain & SAF \\
\hline Specific conductance & $\mu \mathrm{S} / \mathrm{cm}$ & 434 & 657 & 104 & 212 & 321 \\
\hline Nitrate & $\mathrm{mg} / \mathrm{L}$ as $\mathrm{N}$ & 3.3 & 5.4 & 0.22 & 2.4 & 2.3 \\
\hline SRP & $\mathrm{mg} / \mathrm{L}$ as $\mathrm{P}$ & 0.18 & 0.092 & 0.029 & 0.10 & 0.22 \\
\hline Magnesium & $\mathrm{mg} / \mathrm{L}$ & 14 & 25 & 4.2 & 5.9 & 9.2 \\
\hline Potassium & $\mathrm{mg} / \mathrm{L}$ & 5.4 & 6.7 & 1.1 & 3.3 & 4.7 \\
\hline Sodium & $\mathrm{mg} / \mathrm{L}$ & 25 & 41 & 4.7 & 12 & 17 \\
\hline Chloride & $\mathrm{mg} / \mathrm{L}$ & 11 & 17 & 2.1 & 3.4 & 7.1 \\
\hline Sulfate & $\mathrm{mg} / \mathrm{L}$ & 34 & 68 & 3.1 & 7.6 & 17 \\
\hline
\end{tabular}

\footnotetext{
${ }^{1}$ Median discharge measured in DR2 (site W13) from mid-October 2003 through mid-March 2004, adjusted by the ratio of nonirrigation-to-irrigation season
} hydraulic gradient from ground water to surface water.

contribution of solutes to DR2. Estimates of recharge dates for the ground water sampled (fig. 9) indicate that time spent in the subsurface is on the order of several years to several decades. Therefore, in addition to chemical changes in the water that result from its passage through the subsurface, some of the differences between SAF and base flow may be the result of changes in agricultural practices over the past several decades.

In contrast to the major solutes, the calculated concentration of nitrate in SAF was nearly an order of magnitude greater than the median concentration measured in canal water (fig. 17A), but only about 30 percent of the median concentration measured in base flow. The SRP concentration in SAF was more than six times greater than the median measured in canal water (fig. 17D), and twice the median concentration measured in base flow.

SAF compared to field drain discharge.-SAF concentrations calculated for most of the major solutes, as well as nitrate, were similar to the median concentrations measured in water from the field drain (W42). This similarity indicates that with respect to most major solutes (calcium, magnesium, potassium, sodium, and silica), the net effect of sources and transport processes in the field from which drainage was sampled was similar to the net effect of sources and processes throughout the catchment as a whole. At both the field scale and the catchment scale, soil-water interaction and dissolution of applied fertilizers and soil amendments probably accounted for virtually all of these solutes.

In contrast to the major solutes mentioned above, concentrations of SRP, chloride, and sulfate were dissimilar in SAF and the field drain. Concentrations of SRP, chloride, and sulfate calculated for SAF were approximately two times the median concentrations measured in water from the field drain. These differences indicate that the sources of these solutes and (or) the processes affecting their transport and fate in the catchment as a whole are not closely approximated by sources and processes governing water quality at site W42.

Given the inherently complex, highly variable nature of field-scale runoff processes (Durand and others 1999; Langlois and Mehuys, 2003; Cerdan and others, 2004; Kurz and others, 2005), the variety of cropping, irrigation, tillage, and drainage practices used across DR2, and ongoing nearstream and instream biochemical processes, even the concentrations of SRP, chloride, and sulfate calculated for SAF are remarkably similar to the median concentrations measured in water from the field drain. 

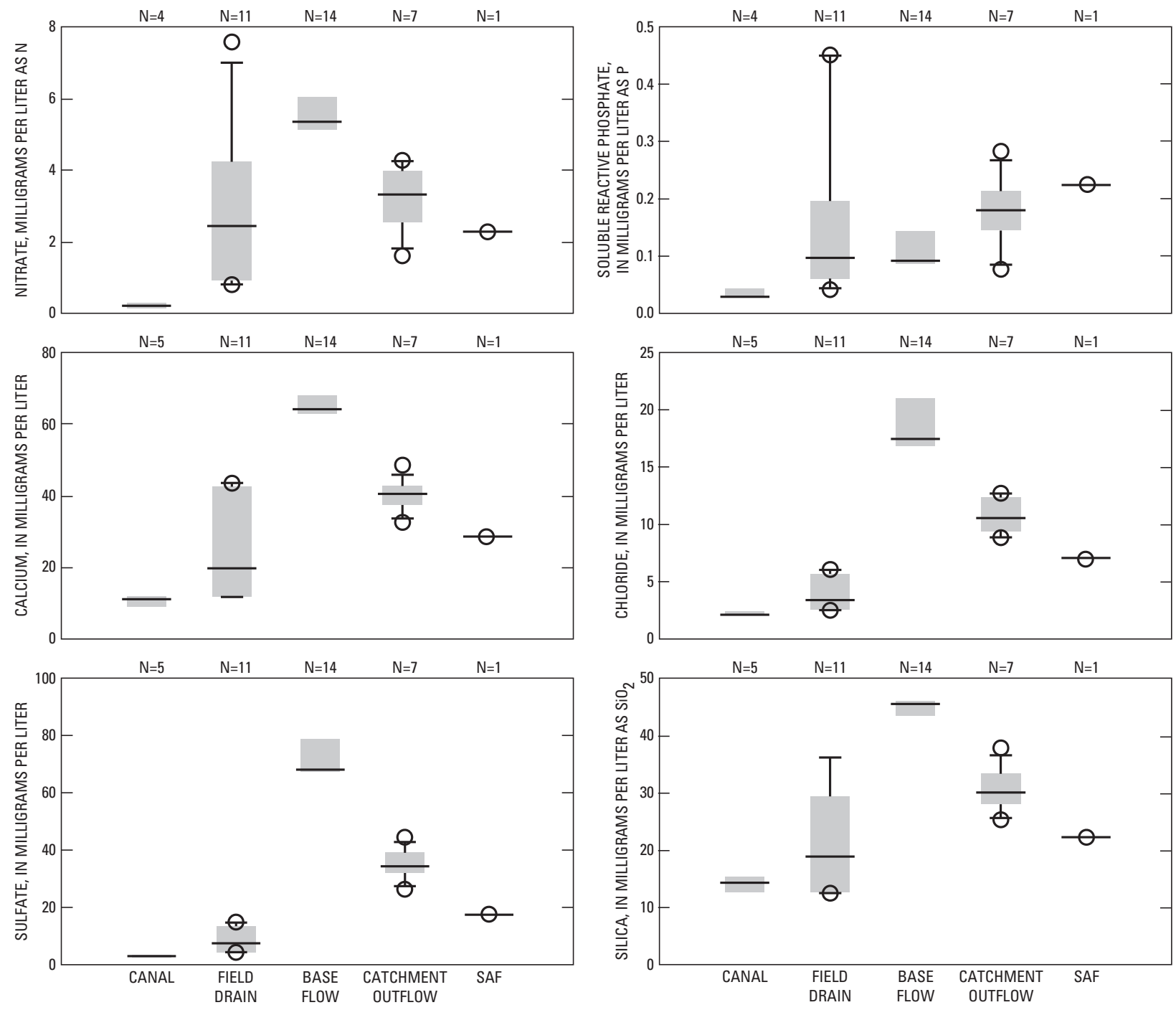

EXPLANATION

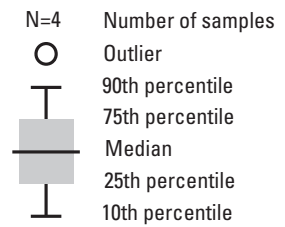

Figure 17. Distribution of concentrations of selected solutes measured in the DR2 catchment outflow components, and concentrations calculated for hypothetical seasonal agricultural flow (SAF), Yakima River basin, Washington. 


\section{Summary and Conclusions}

Hydrologic and water-chemistry data from several environmental compartments were used to develop an understanding of water flow and solute transport in a small, irrigated agricultural catchment. An inverse end-member mixing analysis then was used to gain a fuller understanding of solute sources and transport in the catchment. Considering the variation in crops and irrigation methods both across the catchment and over time, this approach indicates that during the study period, the net effect of processes in the catchment as a whole produced similar concentrations of most major solutes as the net effect of processes in the single field from which drainage was sampled. Data from two sampling transects in the streambed provided evidence that ground-water flow from different source areas converges to discharge to the surface near the catchment outlet, and provided insight into differences between the chemistry of relatively deep ground water that discharges upward into the stream and that of shallow ground water that flows laterally into the stream.

This work indicates that combining irrigation and artificial-drainage networks may exacerbate the ecological effects of agricultural runoff by increasing direct connectivity between fields and streams and minimizing potentially mitigating effects of longer subsurface pathways such as denitrification and dilution.

\section{Acknowledgments}

This work was conducted as part of the USGS National Water Quality Assessment Program, and many individuals contributed to its success.

\section{References Cited}

Böhlke, J.K., Wanty, R., Tuttle, M., Delin, G., and Landon, M., 2002, Denitrification in the recharge area and discharge area of a transient agricultural nitrate plume in a glacial outwash sand aquifer, Minnesota: Water Resources Research, v. 38, no. 7, p. 101-1026.

Capel, P.D., McCarthy, K.A., and Barbash, J.E, 2008, National, holistic, watershed-scale approach to understand the sources, transport, and fate of agricultural chemicals: Journal of Environmental Quality, v. 37, no. 3, p. 983-993.

Cerdan, O., Le Bissonnais, Y., Govers, G., Lecomte, V., Van Oost, K., Couturier, A., and others, 2004, Scale effect on runoff from experimental plots to catchments in agricultural areas in Normandy: Journal of Hydrology, v. 299, no. 1-2, p. 4-14.
Domagalski, J.L., Ator, S., Coupe, R., McCarthy, K., Lampe, D., Sandstrom, M., and others, 2008, Comparative study of transport processes of nitrogen, phosphorus, and herbicides to streams in five agricultural basins, USA: Journal of Environmental Quality, v. 37, no. 3, p. 1158-1169.

Duff, J.H., Tesoriero, A.J., Richardson, W.B., Strauss, E.A., and Munn, M.D., 2008, Whole-stream response to nitrate loading in three streams draining agricultural landscapes: Journal of Environmental Quality, v. 37, no. 3, p. 11331144 .

Dunkle, S.A., Plummer, L.N., Busenberg, E., Phillips, P.J., Denver, J., Hamilton, P.A., Michel, R.L., and Coplen, T.B., 1993, Chlorofluorocarbons ( $\mathrm{CCl} 3 \mathrm{~F}$ and $\mathrm{CCl} 2 \mathrm{~F} 2)$ as dating tools and hydrologic tracers in shallow groundwater of the Delmarva Peninsula, Atlantic coastal plain, United States: Water Resources Research, v. 29, no. 12, p. 3837-3860.

Durand, P., Cros-Cayot, S., Gascuel-Odoux, C., and Heddadj, D, 1999, Solute concentrations of overland flow water in a cultivated field - Spatial variations, intra- and inter-storm trends: Hydrological Processes, v. 13, no. 10, p. 1465-1477.

Ebbert, J.C., Embrey, S.S., and Kelley, J.A., 2003, Concentrations and loads of suspended sediment and nutrients in surface water of the Yakima River basin, Washington, 1999-2000 [electronic resource]-With an analysis of trends in concentrations: U.S. Geological Survey Water-Resources Investigations Report 2003-4026, 111 p.

Eisenhauer, D., Bjorneberg, D., and Westermann, D., 2006, Water management practices-Irrigated cropland, in Schnepf, Max, and Cox, Craig, Environmental benefits of conservation on cropland - The status of our knowledge: Ankeny, Iowa, Soil and Water Conservation Society, p. 132-148.

Essaid, H.I., Zamora, C.M., McCarthy, K.A., Vogel, J.R., and Wilson, J.T., 2008, Using heat to characterize streambed water flux variability in four stream reaches: Journal of Environmental Quality, v. 37, no. 3, p. 1010-1023.

Fuhrer, G.J., Morace, J.L., Johnson, H.M., Rinella, J.F., Ebbert, J.C., Embrey, S.S., and others, 2004, Water quality in the Yakima River basin, Washington, 1999-2000: U.S. Geological Survey Circular 1237, 44 p.

Gollehon, N., and Quinby, W., 2000, Irrigation in the American west - Area, water and economic activity: International Journal of Water Resources Development, v. 16 , no. 2 , p. 187.

Green, C.T., Puckett, L.J., Böhlke, J.K., Bekins, B.A., Phillips, S.P., Kauffman, L.J., and others, 2008, Limited occurrence of denitrification in four shallow aquifers in agricultural areas of the United States: Journal of Environmental Quality, v. 37, no. 3, p. 994-1009. 
Green, R.E., Cornell, S.J., Scharlemann, J.P.W., and Balmford, A., 2005, Farming and the fate of wild nature: Science, v. 307 , no. 5709 , p. 550-555.

Harbaugh, A.W., Banta, E.R., Hill, M.C., and McDonald, M.G, 2000, MODFLOW-2000, the U.S. Geological Survey modular ground-water model-User guide to modularization concepts and the ground-water flow process: U.S. Geological Survey Open-File Report 2000-92, 121 p.

Heaton, T.H.E., and Vogel, J.C, 1981, 'Excess air' in groundwater: Journal of Hydrology, v. 50, no. 1-3, p. 201-216.

Kendall, C, 1998, Tracing nitrogen sources and cycles in catchments, in Kendall, C., and McDonnell, J.J., eds., Isotope tracers in catchment hydrology: Amsterdam, Elsevier, p. 519-576.

Kurz, I., Coxon, C., Tunney, H., and Ryan, D., 2005, Effects of grassland management practices and environmental conditions on nutrient concentrations in overland flow: Journal of Hydrology, v. 304, no. 1-4, p. 35-50.

Langlois, J.L., and Mehuys, G.R., 2003, Intra-storm study of solute chemical composition of overland flow water in two agricultural fields: Journal of Environmental Quality, v. 32, no. 6 , p. 2301-2310.

Lapham, W.W., Wilde, F.D., and Koterba, M.T., 1997, Guidelines and standard procedures for studies of groundwater quality; selection and installation of wells, and supporting documentation: U.S. Geological Survey WaterResources Investigations Report 96-4233, 110 p.

Payne, K.L., Johnson, H.M., and Black, R.W., 2007, Environmental setting of the Granger Drain and DR2 basins, Washington, 2003-04: U.S. Geological Survey Scientific Investigations Report 2007-5102, 26 p., accessed July 21, 2008 at http://pubs.usgs.gov/sir/2007/5102/
Pollock, D.W., 1994, User's guide for MODPATH/ MODPATH-PLOT, version 3; a particle tracking postprocessing package for MODFLOW, the U.S. Geological Survey finite-difference ground-water flow model: U.S. Geological Survey Open-File Report 94-464, 248 p.

Puckett, L.J., Zamora, C., Essaid, H., Wilson, J.T., Johnson, H.M., Brayton, M.J., and others, 2008, Transport and fate of nitrate at the ground-water/surface-water interface: Journal of Environmental Quality, v. 37, no. 3, p. 1034-1050.

Schaible, Glenn, 2004, Irrigation, water conservation, and farm size in the Western United States: Amber Waves, June 2004, accessed January 18, 2007, at http://www.ers.usda. gov/AmberWaves/June04/findings/IrrigationWestern.htm

Schwank1, L.J., Prichard, T.L., and Hanson, B.R., 2007, Tailwater return systems: University of California, Agricultural and Natural Resources Publication 8225, 10 p.

Steele, G.V., Johnson, H.M., Sandstrom, M.W., Capel, P.D., and Barbash, J.E, 2008, Occurrence and fate of pesticides in four contrasting agricultural settings in the United States: Journal of Environmental Quality, v. 37, no. 3, p. 11161132.

U.S. Environmental Protection Agency, 2002, 2000 National Water Quality Inventory: Washington, DC., U.S. Environmental Protection Agency Office of Water, accessed January 22, 2008, at http:/www.epa.gov/305b/2000report/

U.S. Environmental Protection Agency, 2003, National management measures to control nonpoint source pollution from agriculture: U.S. Environmental Protection Agency report EPA 841-B-03-004, 518 p.

U.S. Environmental Protection Agency, 2005, National management measures to control nonpoint source pollution from urban areas: U.S. Environmental Protection Agency report EPA-841-B-05-004, 518 p.

Vogel, J.C., Talma, A.S., and Heaton, T.H.E., 1981, Gaseous nitrogen as evidence for denitrification in groundwater: Journal of Hydrology, v. 50, no. 1-3, p. 191-200. 
Publishing support provided by the U.S. Geological Survey Publishing Network, Tacoma Publishing Service Center

For more information concerning the research in this report, contact the

Director, Oregon Water Science Center

U.S. Geological Survey

2130 SW 5th Avenue

Portland, Oregon 98402

http://or.water.usgs.gov 


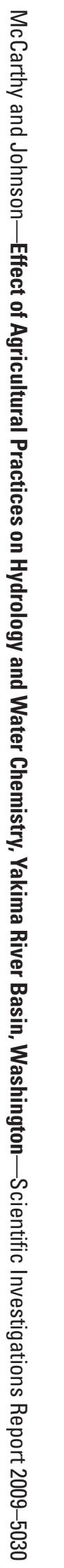

